\title{
Aerosol optical thickness retrieval over land and water using Global Ozone Monitoring Experiment (GOME) data
}

\author{
J. Kusmierczyk-Michulec ${ }^{1}$ and G. de Leeuw \\ Physics and Electronics Laboratory, Netherlands Organization for Applied Scientific Research, The Hague, Netherlands
}

Received 16 March 2004; revised 29 July 2004; accepted 3 August 2004; published 3 March 2005.

[1] An algorithm for the retrieval of the aerosol optical thickness over land and over water from Global Ozone Monitoring Experiment (GOME) data is presented. The cloud fraction in the GOME pixels is determined using the Fast Retrieval Scheme for Clouds From the Oxygen A Band (FRESCO) algorithm. Surface contributions to the top of atmosphere reflectance are determined from the GOME surface reflectance database. The aerosol retrieval algorithm uses lookup tables that were created using the radiative transfer model $6 \mathrm{~S}$. The algorithm allows retrieving the aerosol types characterized by Angstrom coefficients in the range from -0.1 to 2.8 ; i.e., the range of values observed by the AERONET ground-based measurements. Validation of the algorithm done using the AERONET Sun photometer data for 12 sites in Europe and Africa, for the year 1997, shows very good agreement. The correlation coefficient between the satellite retrieval and AERONET data for the wavelength of $440 \mathrm{~nm}$ is $97 \%$, and for $670 \mathrm{~nm}$ it is $94 \%$. Validation of the algorithm for the year 2000 was done for a few sites with similar results. The algorithm has been successfully tested over an island influenced by Saharan dust (i.e., Cape Verde, $16^{\circ} \mathrm{N}$, $22^{\circ} \mathrm{W}$ ) and over a site located near the Saharan desert (i.e., Bondoukoui, $11^{\circ} \mathrm{N}, 3^{\circ} \mathrm{W}$ ). For other sites located near the Saharan desert such as Bidi Bahn $\left(14^{\circ} \mathrm{N}, 2^{\circ} \mathrm{W}\right)$ and Banizombou $\left(13^{\circ} \mathrm{N}, 2^{\circ} \mathrm{E}\right)$, the agreement was very good at $440 \mathrm{~nm}$. The algorithm has not been tested over other bright surfaces such as ice-covered regions. Examples of the spatial distribution of the aerosol optical thickness over Europe, north Africa, and the North Atlantic for the year 1997 and 2000 are presented.

Citation: Kusmierczyk-Michulec, J., and G. de Leeuw (2005), Aerosol optical thickness retrieval over land and water using Global Ozone Monitoring Experiment (GOME) data, J. Geophys. Res., 110, D10S05, doi:10.1029/2004JD004780.

\section{Introduction}

[2] The atmosphere and its composition, especially dust and smoke, have been intensively investigated since the beginning of the 20th century [Gibbs, 1929]. The relation between the amount of dust particles and meteorological phenomena has been studied by Aitken [1890]; air pollution in towns has been described, e.g., by Fyfe [1911] and Cohen and Ruston [1912]. Nowadays, in the époque of satellite observations, aerosols are still a subject of interest because of their properties as well as their influence on climate [e.g., Brasseur et al., 1999].

[3] Aerosols regulate the solar radiative transfer in the atmosphere, causing a change in the net radiation at the top of the atmosphere, as well as changes in horizontal visibility. Recent model calculations indicate that aerosol particles

\footnotetext{
${ }^{1}$ On leave from Institute of Oceanology, Polish Academy of Sciences, Sopot, Poland.

Copyright 2005 by the American Geophysical Union. 0148-0227/05/2004JD004780\$09.00
}

emitted during fossil fuel (e.g., soot) and biomass (organic aerosols) burning, as well as ammonium sulphate and nitrate aerosols, can contribute to the anthropogenic radiative forcing of climate [e.g., Charlson et al., 1991]. However, because the residence time of emitted aerosols is relatively short, in comparison to that of greenhouse gases [e.g., Schwartz, 1996], the climatic influences of aerosols are most important in the immediate vicinity of the source regions.

[4] Satellites are best suited to determine the spatial distribution of aerosols over large areas during extended time periods, needed to evaluate their effects. Satellite observations since more than 25 years provide the aerosol index (AI) from the Total Ozone Mapping Spectrometer (TOMS) [Herman et al., 1997] and, over the oceans, the aerosol optical thickness (AOT) from the Advanced Very High Resolution Radiometer (AVHRR). Instruments become more and more sophisticated, reaching the compromise between spatial and spectral resolution, i.e., the Moderate Resolution Imaging Spectrometer (MODIS) [Kaufman and Tanré, 1996].

[5] Usually, instruments used for aerosol retrieval are designed for this purpose, such as Along Track Scanning 
Radiometer 2 (ATSR-2) or Medium Resolution Imaging Spectrometer (MERIS). In this paper we explore the use of instruments with high spectral resolution, designed for accurate gas phase retrieval, such as GOME, Scanning Imaging Absorption Spectrometer for Atmospheric Chartography (SCIAMACHY) and Ozone Monitoring Instrument (OMI). Because calibrated SCIAMACHY data are not yet available, OMI is planned to be launched in the summer of 2004 therefore GOME data are used in this study. A serious disadvantage is the large GOME pixel size resulting in a very low probability of clear sky pixels which limits the usefulness of GOME for aerosol retrieval, as will be shown. Hence this study must be regarded as a preparation for the retrieval of aerosol properties from SCIAMACHY.

[6] GOME is a 4-channel grating spectrometer, operating in the wavelength range of 237-794 nm with a spectral resolution of $0.2-0.4 \mathrm{~nm}$ [Burrows et al., 1999]. On 21 April 1995, GOME was launched onboard the ERS-2 satellite into a near-polar Sun-synchronous orbit at a mean altitude of about $785 \mathrm{~km}$, with a mean local equator crossing time of 1030 (local time). GOME performs nadir observations by scanning the surface from east $\left(-30^{\circ}\right)$ to west $\left(30^{\circ}\right)$ in $4.5 \mathrm{~s}$. One across-track scan is divided into three $1.5 \mathrm{~s}$ scans, resulting in three GOME ground pixels with an average coverage of $40 \mathrm{~km} \times 320 \mathrm{~km}$. For about $10 \%$ of the time, the swath is reduced to $240 \mathrm{~km}$, and all pixel sizes are four times smaller. Once per day the Sun is observed over a diffuser plate for radiometric calibration.

[7] The application of GOME data to obtain the aerosol maps over water has been presented by Guzzi et al. [2001]. Holzer-Popp et al. [2002] have suggested the combined approach using two instruments: GOME and ATSR-2. Here, an algorithm to derive the aerosol optical thickness from GOME data over both water and land is presented. The advantage of this approach is that it uses only GOME data and the surface reflectance database [Koelemeijer et al., 2003] that is also a GOME product. The algorithm uses the lookup tables (LUTs) that were created using the radiative transfer model 6S [Vermote et al., 1997] for three main aerosol types: maritime, continental and urban [McClatchey et al., 1984]. However, the algorithm allows to retrieve aerosol mixtures characterized by Ångstrom coefficients in the range from -0.1 to 2.8 , i.e., the values observed by the AERONET ground-based measurements [Dubovik et al., 2002].

[8] Detailed information about the Aerosol Robotic Network (AERONET) is presented in the work of Holben et al. [1998]. The description of the data processing and cloud-screening algorithm used by the AERONET is presented in the work of Eck et al. [1999] and Smirnov et al. [2000].

\section{Theory}

[9] The total radiance $L$ received by a sensor at the top of the atmosphere can be presented as the sum of the contributions from aerosols, molecules, and the surface. Instead of radiance $\mathrm{L}$, it is often more convenient to use reflectance, i.e., a dimensionless function, defining the ratio of the measured radiance $\mathrm{L}$ to the solar flux at the top of the atmosphere: $\rho=\pi L / \mu_{s} F_{s}$, where $\mu_{s}=\cos \theta_{s}, \theta_{\mathrm{s}}$ is the solar zenith angle and $\mathrm{F}_{\mathrm{s}}$ is the extraterrestrial solar irradiance. In both representations the molecular contribution is assumed to be well known. The main issue is the separation of the aerosol and surface contributions to the total reflectance.

[10] The reflectance at the top of atmosphere above a Lambertian homogeneous surface with reflectance $\rho_{\text {surf }}$ viewed by a satellite sensor and illuminated by Sun can be described as follows [Tanré et al., 1979]

$$
\rho_{T O A}\left(\theta_{s}, \theta_{v}, \Delta \varphi\right)=T_{g}\left(\theta_{s}, \theta_{v}\right)\left\{\rho_{\text {atm }}+T^{\downarrow}\left(\theta_{s}\right) T^{\uparrow}\left(\theta_{v}\right) \frac{\rho_{\text {surf }}}{1-S \rho_{\text {surf }}}\right\}
$$

The independent parameters in equation (1) are defined as follows:

$\theta_{s}, \varphi_{s}$ zenith and azimuth angles of the direct sunlight;

$\theta_{v}, \varphi_{v}$ view zenith and azimuth angles from a spacecraft toward Earth's surface;

$\Delta \varphi=\varphi_{s}-\varphi_{\nu} ;$

$\rho_{\text {TOA }}$ the total apparent reflectance measured at the satellite level;

$\rho_{\text {atm }}$ the atmospheric reflectance;

$S$ the spherical albedo of the atmosphere, i.e., the normalized irradiance backscattered by the atmosphere when the input irradiance at the bottom is isotropic;

$\rho_{\text {surf }}$ the surface reflectance (land or water);

$T_{g}$ the gaseous transmission;

$T^{\downarrow}\left(\theta_{s}\right), T^{\uparrow}\left(\theta_{v}\right)$ the total transmission of the atmosphere on the path between the Sun and the surface, and respectively, the surface and the sensor.

\subsection{Atmospheric Transmission Functions}

[11] The total transmission of the atmosphere on the path between the Sun and the surface $T^{\downarrow}\left(\theta_{s}\right)$, respectively between the surface and the sensor $T^{\uparrow}\left(\theta_{v}\right)$, can be presented as the product of the Rayleigh transmission function $T_{r}$ [e.g., Lenoble, 1985] and the aerosol transmission function $T_{a}$.

\subsubsection{Rayleigh Transmission Functions}

[12] The analytical formulae for the Rayleigh transmission function can be obtained by applying the Eddington approximation to the radiative transfer equation [Lenoble, 1985]:

$$
T_{r}(\mu, \lambda)=\frac{(2 / 3+\mu)+(2 / 3-\mu) \exp \left(-\tau_{r}(\lambda) / \mu\right)}{4 / 3+\tau_{r}(\lambda)},
$$

where $\mu=\cos \theta(\theta$ is the solar/view zenith angle $), \tau_{r}$ is the Rayleigh optical thickness. Equation (2) is used in the radiative transfer model $6 \mathrm{~S}$.

\subsubsection{Aerosol Transmission Functions}

[13] The aerosol transmission functions were calculated using the radiative transfer model 6S [Vermote et al., 1997] for the following input parameters: (1) solar/view zenith angles $\theta: 0^{\circ}, 10^{\circ}, 20^{\circ}, 30^{\circ}, 35^{\circ}, 40^{\circ}, 45^{\circ}, 50^{\circ}, 55^{\circ}$ and $60^{\circ}$; (2) wavelengths $\lambda$ : $380 \mathrm{~nm}, 440 \mathrm{~nm}, 463 \mathrm{~nm}, 495 \mathrm{~nm}$, $555 \mathrm{~nm}$ and $670 \mathrm{~nm}$; (3) aerosol types: maritime, continental and urban [McClatchey et al., 1984]; and (4) aerosol optical thickness $\tau_{\mathrm{a}}(555 \mathrm{~nm}): 0,0.1,0.2,0.3,0.4,0.55,0.8$ 
Table 1. Overview of the Values of Real $n(\lambda)$ and Imaginary Parts $k(\lambda)$ of the Refractive Index, As Well As Single Scattering Albedo $\omega(\lambda)$ for the Basic Aerosol Components Used in the WCP Model [McClatchey et al., 1984]

\begin{tabular}{|c|c|c|c|}
\hline$\lambda, \mathrm{nm}$ & $\omega(\lambda)$ & $n(\lambda)$ & $k(\lambda)$ \\
\hline \multicolumn{4}{|c|}{ Dust-Like Particles } \\
\hline 380 & 0.62 & 1.53 & 0.008 \\
\hline 440 & 0.63 & 1.53 & 0.008 \\
\hline 463 & 0.64 & 1.53 & 0.008 \\
\hline 495 & 0.64 & 1.53 & 0.008 \\
\hline 555 & 0.65 & 1.53 & 0.008 \\
\hline 670 & 0.67 & 1.53 & 0.008 \\
\hline \multicolumn{4}{|c|}{ Water-Soluble Particles } \\
\hline 380 & 0.96 & 1.53 & 0.005 \\
\hline 440 & 0.96 & 1.53 & 0.005 \\
\hline 463 & 0.96 & 1.53 & 0.005 \\
\hline 495 & 0.96 & 1.53 & 0.005 \\
\hline 555 & 0.96 & 1.53 & 0.006 \\
\hline 670 & 0.95 & 1.53 & 0.006 \\
\hline \multicolumn{4}{|c|}{ Oceanic Particles } \\
\hline 380 & 1.0 & 1.39 & $4.5 \mathrm{E}-8$ \\
\hline 440 & 1.0 & 1.38 & $8.3 \mathrm{E}-9$ \\
\hline 463 & 1.0 & 1.38 & $7.5 \mathrm{E}-9$ \\
\hline 495 & 1.0 & 1.38 & $5.7 \mathrm{E}-9$ \\
\hline 555 & 1.0 & 1.38 & 4.3E-9 \\
\hline 670 & 1.0 & 1.38 & $3.7 \mathrm{E}-8$ \\
\hline \multicolumn{4}{|c|}{ Soot Particles } \\
\hline 380 & 0.28 & 1.75 & 0.463 \\
\hline 440 & 0.25 & 1.75 & 0.456 \\
\hline 463 & 0.24 & 1.75 & 0.453 \\
\hline 495 & 0.23 & 1.75 & 0.450 \\
\hline 555 & 0.21 & 1.75 & 0.440 \\
\hline 670 & 0.17 & 1.75 & 0.430 \\
\hline
\end{tabular}

and 1.Next, an empirical formula, which form was indicated by equation (2), was fitted to these discrete values to allow for a fast and a very accurate calculation of all intermediate values. The maximum relative error between the empirical formula (see equation (3)) and the 6S results is \pm 0.0003 $( \pm 0.03 \%)$

$$
T_{a}(\lambda, \mu, h)=\exp \left\{-\frac{\tau_{a}(\lambda, h)}{4 \mu}\right\}\left\{\sum_{i=1}^{3} t_{i}(\mu, \lambda) \tau_{a}^{i}(\lambda, h)+1\right\},
$$

where $h=\tau_{a}(555)$. The functions $t_{i}(\mu)$ for a given $\lambda$ depend on $\mu$ and the aerosol type.

\subsection{Spherical Albedo of the Atmosphere}

[14] The spherical albedo of the atmosphere was calculated using the radiative transfer model, for the same input parameters as in the case of the aerosol transmittance (section 2.2). The values were approximated by third-order polynomials

$$
S(\lambda, h)=\sum_{m=0}^{3} s_{m}(\lambda) \tau_{a}^{m}(\lambda, h)
$$

For $\tau_{\mathrm{a}} \rightarrow 0$ the spherical albedo of the atmosphere reaches the value of the spherical albedo for the molecular scattering: $\mathrm{S}(\lambda, \mathrm{h}) \rightarrow \mathrm{S}_{\mathrm{R}}(\lambda)$, i.e., $\mathrm{s}_{0}(\lambda) \rightarrow \mathrm{S}_{\mathrm{R}}(\lambda)$.

\subsection{Atmospheric Reflectance}

[15] The atmospheric reflectance $\rho_{\text {atm }}$ is the sum of the molecular reflectance, called Rayleigh's reflectance $\rho_{r}$, aerosol reflectance $\rho_{a}$, and the coupling term $\rho_{\text {ra }}$, which takes into account the interaction between molecules and aerosols. The relation between the atmospheric reflectance $\rho_{\text {atm }}$, and the aerosol optical thickness $\tau_{a}$, for different wavelengths $\lambda$, and the scattering angle $\Theta$ that is a function of the zenith angles $\theta_{s}, \theta_{v}$, and the azimuth angle $\Delta \varphi=\varphi_{s}$ $\varphi_{v}$, may be written in a general form as:

$$
\rho_{a t m}(\lambda, \Theta)=\frac{1}{4 \cos \theta_{s} \cos \theta_{v}} \sum_{i=0}^{4} B_{i}(\lambda, \Theta) \tau_{a}^{i}(\lambda, h) .
$$

The values of $\mathrm{B}_{\mathrm{i}}$ depend on the aerosol type, the wavelength and the scattering angle. The number of terms in equation (5) depends on the aerosol type and the wavelength.

\section{Description of the Algorithm}

[16] The GOME aerosol retrieval algorithm uses the measured TOA reflectances, averaged over a $1 \mathrm{~nm}$ wide wavelength window, and centered at $380 \mathrm{~nm}, 440 \mathrm{~nm}$, $463 \mathrm{~nm}, 495 \mathrm{~nm}, 555 \mathrm{~nm}$ and $670 \mathrm{~nm}$.

[17] The calibration procedure of the raw GOME TOA radiances is described in detail by Koelemeijer et al. [2003]. The altitude correction of land pixels was done using the information about the ground pressure, that was found from the ETOPO-5 database [Haxby et al., 1983]. The solar and viewing angles were averaged over the GOME ground pixels. Pixels with solar zenith angles larger than $60^{\circ}$ were discarded.

Figure 1. Each time the aerosol optical thickness is calculated from the atmospheric reflectance, assuming three possible aerosol types: maritime, continental and urban. The solution is marked as an "output." The known aerosol optical thickness that corresponds to the known atmospheric reflectance (input) is also plotted. The calculations are performed for the scattering angle $\Theta=140^{\circ}$. The input aerosol type is: (a) urban, (b) continental, (c) maritime, (d) biomass, and (e) desert dust. (f) The error, defined as a difference between the desert dust aerosol type and the maritime aerosol type. Also shown is an illustration of the retrieval process using the real measurements: (g) The Angstrom coefficient for the maritime aerosol type is 0.23 , i.e., very close to the measured one $(0.21)$. The continental aerosol type also gives very similar value of the Angstrom coefficient (0.29), but this value is outside the continental domain (see section 3.1). The urban aerosol type gives unrealistic spectrum; therefore it is rejected. Therefore our algorithm selects the maritime aerosol type. (h) Similar situation as in Figure 1g. In addition, the continental aerosol type gives a very unrealistic spectrum; therefore it is rejected. (i) Both maritime and continental aerosol types have very strange spectral behavior. The Angstrom coefficient for the urban aerosol type gives a reasonable value; therefore this aerosol type is selected. 
a)

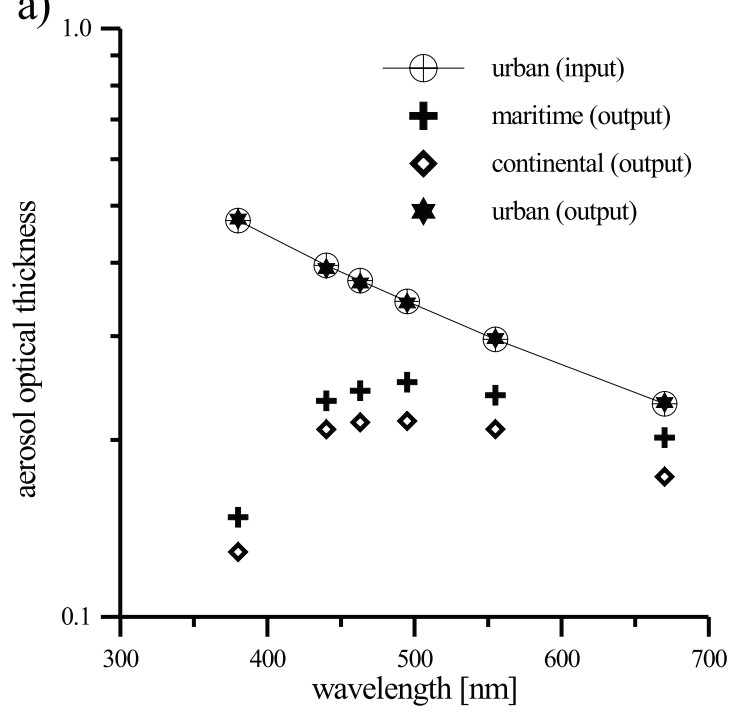

c)

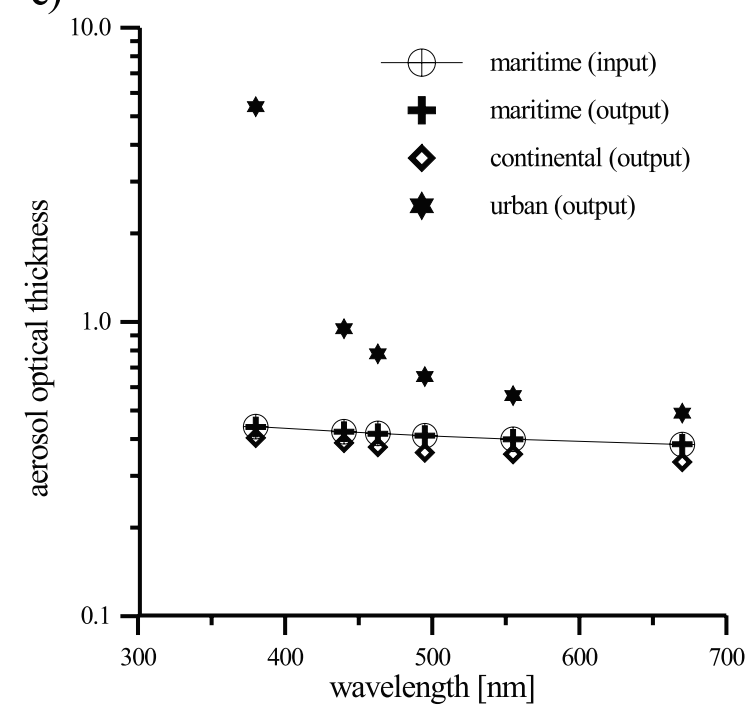

e)

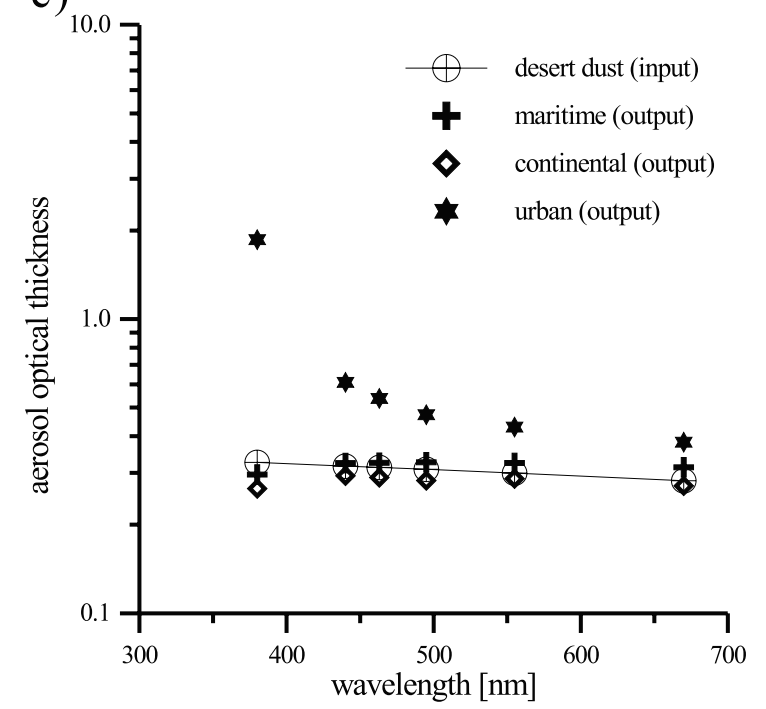



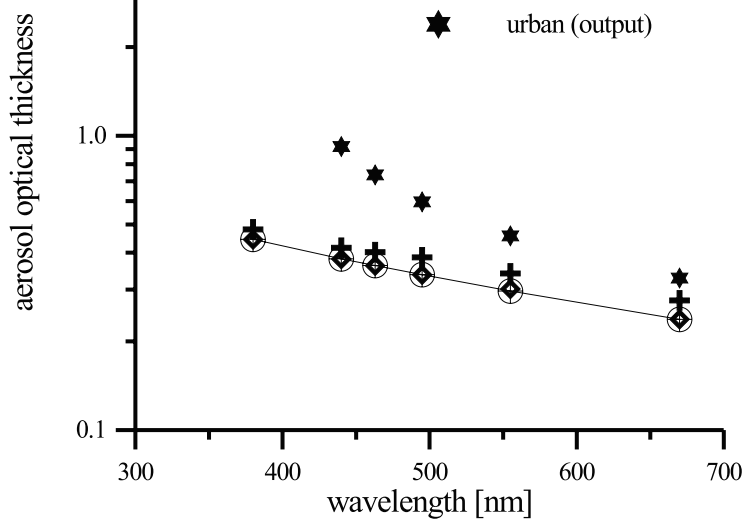

d)

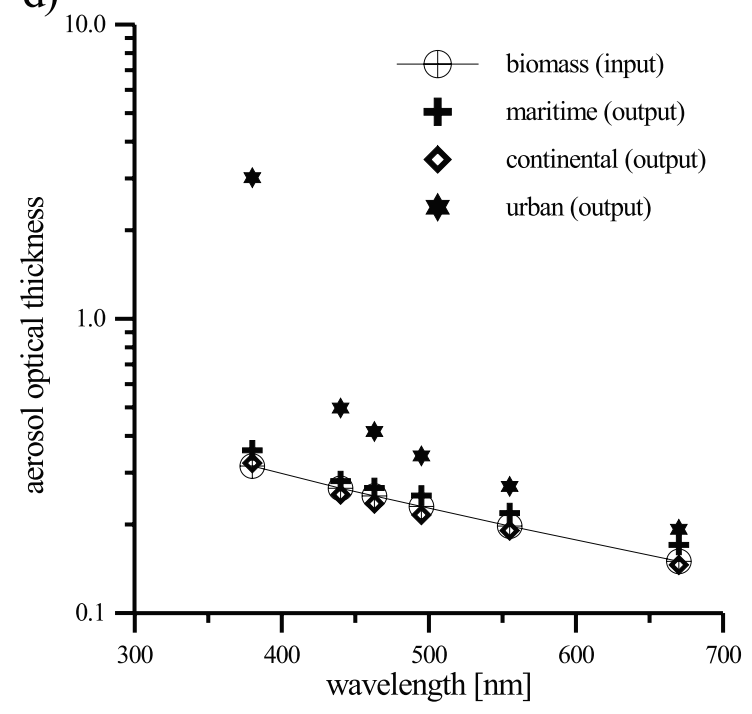

f)

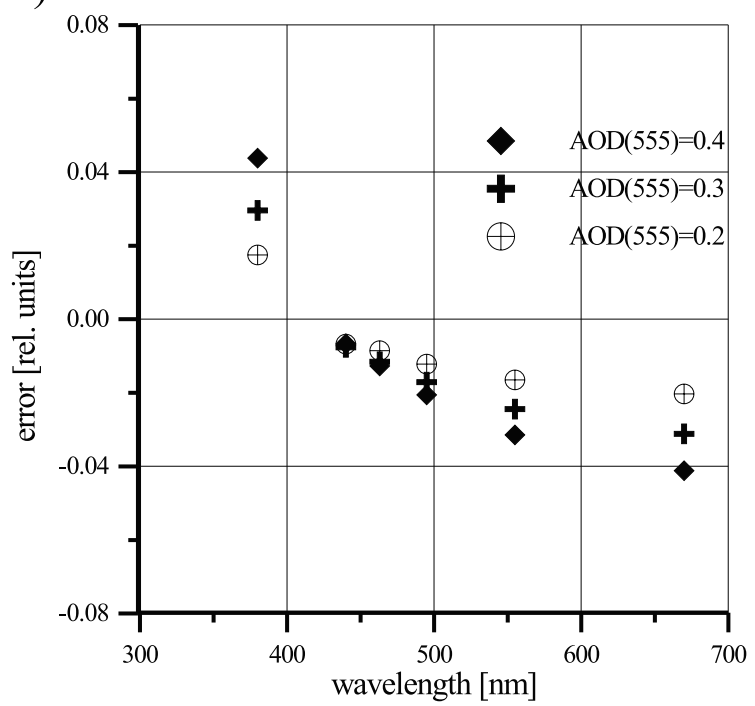

Figure 1 

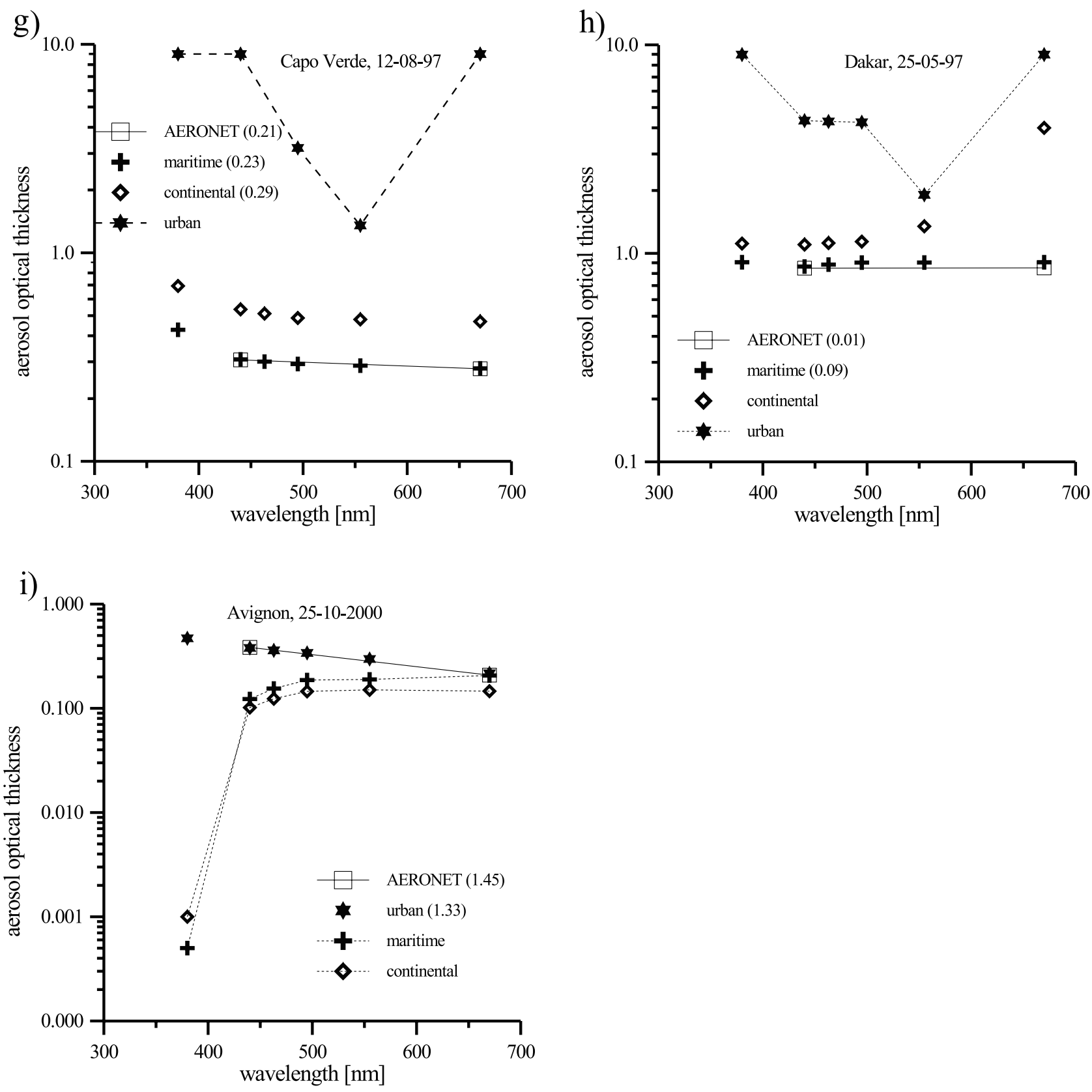

Figure 1. (continued)

[18] Next, the GOME data were corrected for the presence of clouds. The cloud fraction is determined using the Fast Retrieval Scheme for Clouds From the Oxygen A Band (FRESCO) algorithm [Koelemeijer et al., 2001, 2002]. The FRESCO method allows to derive the effective cloud fraction and cloud pressure, using the oxygen A band and its feature. For further retrieval are used only data for which the cloud fraction is less than $0.06(6 \%)$. This criterion results in rejection of more than $80 \%$ of data. The validation of the results with cloud-free AERONET [Holben et al., 1998] level 2.0 data shows that this assumption is reasonable, in some cases may be even too strict.
[19] In the next step, the GOME data at $440 \mathrm{~nm}, 463 \mathrm{~nm}$, $495 \mathrm{~nm}, 555 \mathrm{~nm}$ and $670 \mathrm{~nm}$ are corrected for ozone absorption. At $380 \mathrm{~nm}$ there is no ozone absorption. For these selected wavelengths there is no absorption by other gases that are taken into account by the $6 \mathrm{~S}$ model.

[20] To solve equation (1), the analytical functions given by equations (3), (4), and (5) are used. These functions are empirical relations describing discrete values calculated from the radiative transfer model $6 \mathrm{~S}$. The three main aerosol types: maritime, continental and urban, included in $6 \mathrm{~S}$, are described by the model of the World Climate Programme (WCP) [McClatchey et al., 1984]. The construction of WCP model is based on "external mixing." It is assumed that 
both continental and urban aerosol types are composed of soot, water-soluble and dust-like particles, mixed with the proper volume percentage of each component. The percentage contribution of soot particles is taken as $1 \%$ in the continental aerosol type and $22 \%$, in the urban aerosol type. The maritime aerosol type is composed of sea-salt particles $(95 \%)$ and water-soluble particles $(5 \%)$. The values of real $n(\lambda)$ and imaginary parts $k(\lambda)$ of the refractive index, as well as single scattering albedo $\omega(\lambda)$ for the basic aerosol components used in the WCP model are listed in Table 1.

[21] The main idea of the aerosol retrieval algorithm is that after correction for the surface contribution to the TOA reflectance (described in section 3.2), the solution of equation (1) is searched in three domains of possible solutions: maritime, continental and urban, applying a bisection procedure [Press et al., 1992]. The threshold values of the aerosol optical thickness at $380 \mathrm{~nm}$ and $440 \mathrm{~nm}$ are assumed to be 1.5 , for the other wavelengths, is 1 .

\subsection{Selection of the Most Probable Aerosol Type}

[22] In order to select the most plausible aerosol type the spectral dependence of the aerosol optical thickness, and the expected range of values of the Angstrom coefficients $\alpha$ for a given aerosol type are taken into account. We assume that for predominantly "maritime" aerosol, the Angstrom coefficient $\alpha \in\langle-0.1 ; 0.65\rangle$, for predominantly "continental" aerosol $\alpha \in\langle 0.65 ; 1.32\rangle$, and for predominantly "urban" aerosol $\alpha \in\langle 1.32 ; 2.8\rangle$. This distinction is based on earlier studies on the relations between the aerosol composition, and the values of the Angstrom coefficients [KusmierczykMichulec et al., 1999, 2001, 2002; Kusmierczyk-Michulec and Marks, 2000].

[23] Figures 1a-1e show five model simulations. Each time the aerosol optical thickness is calculated from the atmospheric reflectance, assuming three possible aerosol types: maritime, continental and urban. The solution is marked as an "output." The known aerosol optical thickness accompanying the known atmospheric reflectance (input) is also plotted for comparison. The calculations presented here were performed for the scattering angle $\Theta=140^{\circ}$. It is noted that such model simulations were also done for other possible scattering angles, and the results were similar.

[24] If the "true" type is the urban aerosol type (Figure 1a) the "maritime" and "continental" solutions do not resemble the typical power law curves. This effect is independent of the value of the aerosol optical thickness. If the "true" aerosol type is continental (Figure 1b), maritime (Figure 1c) or a mixed continental maritime, then both curves, i.e., one representing the maritime solution and the second describing the continental solution, are parallel (on the logarithmic scale), characterized by nearly the same values of the Angstrom coefficient. However, the "urban" solution reaches extremely high values, especially in the UV region.

[25] Figures 1d and 1e present situations when the "true" aerosol type is outside the LUT. In both cases the aerosol optical thickness and the atmospheric reflectance representing biomass (Figure 1d) and desert dust (Figure 1e) aerosol types were created using $6 \mathrm{~S}$, and the biomass burning aerosol model is deduced from measurements taken by

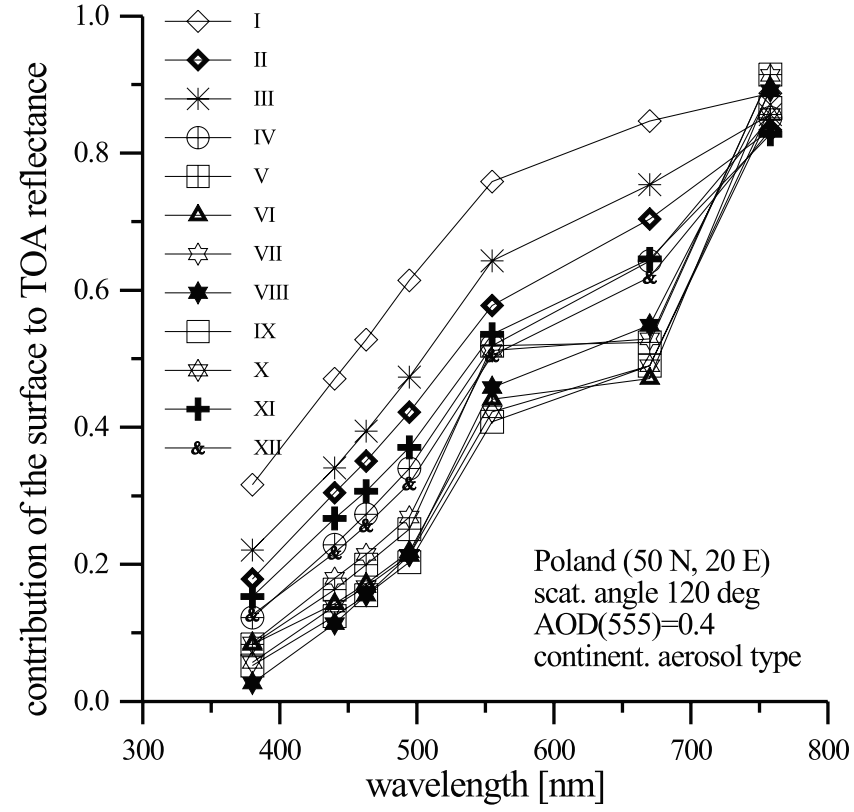

Figure 2. Example of the contribution of the surface term, i.e., $\mathrm{T} \uparrow \mathrm{T} \downarrow * \mathrm{R}_{\text {surf }} /\left(1-\mathrm{S} \mathrm{R}_{\text {surf }}\right)$ to the TOA reflectance for 12 months evaluated for a pixel in Poland $\left(50^{\circ} \mathrm{N}, 20^{\circ} \mathrm{E}\right)$. Calculations are performed for the scattering angle $\Theta=$ $120^{\circ}$; the continental aerosol type and the aerosol optical thickness $\operatorname{AOD}(555)=0.4$. The very high contribution for January, February, and March is due to the presence of snow.

Sun photometers in Amazonia; however, the desert dust aerosol model is described in the work of Shettle [1984].

[26] In both situations the true aerosol types have to be described by their substitutes: the biomass aerosol type by the continental solution, and the desert dust aerosol type by the maritime solution. The question arises what error is involved. In case of the biomass aerosol type, the value of the Angstrom coefficient (in the range $440 \mathrm{~nm}$ to $670 \mathrm{~nm}$ ) is 1.3649. The value of the Angstrom coefficient given by the maritime solution is 1.156 , and by the continental solution 1.307. The first value is outside the domain of the maritime solutions, therefore is rejected. The second value belongs to the domain of the "continental" solutions, therefore is selected. The absolute error is 0.01 for $440 \mathrm{~nm}, 0.002$ for $670 \mathrm{~nm}$, and for $380 \mathrm{~nm}$ is a bit higher, 0.02. Figure $1 \mathrm{f}$ shows the error being the result of replacement the "true" desert dust aerosol type by the maritime solutions. It is clear that the smaller value of the aerosol optical thickness, AOD (555), the smaller is the error. The smallest error is in the range of wavelengths between $440 \mathrm{~nm}$ (around 0.006) and $495 \mathrm{~nm}$ (around 0.02), the biggest error is for $380 \mathrm{~nm}$ and $670 \mathrm{~nm}$ (around 0.04). It means that this approach can be applicable in the small range of wavelengths, especially at $440 \mathrm{~nm}$, because the error is negligible.

[27] The retrieval process using the real observation data is illustrated in Figures $1 \mathrm{~g}$ and $1 \mathrm{i}$. However, the maritime and continental aerosol types may have very similar match with the TOA reflectance, the distinction between them is possible and is based on comparison of their Angstrom coefficients. 
Table 2. Summary of Intercomparison Between the GOME Retrieval and the AERONET Sun Photometer Data ${ }^{\mathrm{a}}$

\begin{tabular}{|c|c|c|c|c|c|c|c|c|}
\hline Site & Location & Period & N1 & $|\Delta \tau(440)|$ & $\mathrm{R}_{1}$ & $\mathrm{~N} 2$ & $|\Delta \tau(670)|$ & $\mathrm{R}_{2}$ \\
\hline Banizombou & $13 \mathrm{~N}, 2 \mathrm{E}$ & $\begin{array}{l}\text { January to } \\
\text { October } 1997\end{array}$ & 5 & 0.028 & 0.99 & - & - & - \\
\hline Bondoukoui & $11 \mathrm{~N}, 3 \mathrm{~W}$ & $\begin{array}{l}\text { January to } \\
\text { December } 1997\end{array}$ & 27 & 0.043 & 0.95 & 14 & 0.034 & 0.96 \\
\hline Barbados & $13 \mathrm{~N}, 59 \mathrm{~W}$ & $\begin{array}{l}\text { January to } \\
\text { November } 1997\end{array}$ & 7 & 0.031 & 0.89 & 6 & 0.037 & 0.99 \\
\hline Capo Verde & $16 \mathrm{~N}, 22 \mathrm{~W}$ & $\begin{array}{l}\text { January to } \\
\text { December } 1997\end{array}$ & 8 & 0.024 & 0.98 & 7 & 0.018 & 0.99 \\
\hline Rame Head & $50 \mathrm{~N}, 4 \mathrm{~W}$ & $\begin{array}{c}\text { April to July } \\
1997\end{array}$ & 6 & 0.054 & 0.86 & 5 & 0.055 & 0.97 \\
\hline Bidi Bahn & $14 \mathrm{~N}, 2 \mathrm{~W}$ & $\begin{array}{c}\text { January to September } \\
1997\end{array}$ & 12 & 0.066 & 0.90 & - & - & - \\
\hline Dakar & $14 \mathrm{~N}, 16 \mathrm{~W}$ & $\begin{array}{c}\text { January to July } \\
1997\end{array}$ & 6 & 0.061 & 0.94 & 1 & 0.018 & - \\
\hline GSFC & $39 \mathrm{~N}, 76 \mathrm{~W}$ & $\begin{array}{l}\text { February to } \\
\text { November } 1997\end{array}$ & 13 & 0.045 & 0.89 & - & - & - \\
\hline Lille & $50 \mathrm{~N}, 3 \mathrm{E}$ & $\begin{array}{l}\text { June to } \\
\text { September } 1997\end{array}$ & 4 & 0.032 & 0.97 & 3 & 0.034 & - \\
\hline Ispra & $45 \mathrm{~N}, 8 \mathrm{E}$ & $\begin{array}{l}\text { August to } \\
\text { November } 1997\end{array}$ & 4 & 0.059 & 0.92 & 3 & 0.044 & - \\
\hline Bermuda & $32 \mathrm{~N}, 64 \mathrm{~W}$ & December 1997 & 2 & 0.008 & - & 1 & 0.002 & - \\
\hline Aire Adour & $43 \mathrm{~N}, 0 \mathrm{E}$ & $\begin{array}{l}\text { February to } \\
\text { November } 1997\end{array}$ & 8 & 0.037 & 0.72 & 8 & 0.053 & 0.50 \\
\hline
\end{tabular}

${ }^{\mathrm{a}} \mathrm{Here} \mathrm{N} 1$ and $\mathrm{N} 2$ are the number of samples at wavelengths of $440 \mathrm{~nm}$ and $670 \mathrm{~nm} .|\Delta \tau(440)|$ and $|\Delta \tau(670)|$ are the mean absolute differences between satellite and Sun photometer measurements at 440 and $670 \mathrm{~nm}$, respectively. $\mathrm{R}_{1}$ and $\mathrm{R}_{2}$ are the correlation coefficients between the GOME and AERONET aerosol optical thickness values at 440 and $670 \mathrm{~nm}$, respectively. The correlation coefficients are given for $\mathrm{N} \geq 4$.

\subsection{Surface Correction}

[28] One of the crucial issues is the proper surface correction, especially over land. Thus the selection of wavelengths in the spectral range between $380 \mathrm{~nm}$ and $670 \mathrm{~nm}$ was not coincidental. The reason was that in that range the contribution of the surface term, i.e., $T \uparrow T \downarrow * R_{\text {surf }} \downarrow$ $\left(1-\mathrm{S} \mathrm{R}_{\text {surf }}\right)$ (see equation (1)) to the TOA reflectance is not higher than $60 \%$ (except in the case of snow). This contribution increases with wavelength reaching a value of around $80 \%$ at $770 \mathrm{~nm}$ (see Figure 2). These numbers are based on the analysis of the surface reflectances taken from the GOME surface reflectance database [Koelemeijer et al., 2003].

[29] In this database are stored the minimum Lambert equivalent reflectivity (LER) values which occurred in the period June 1995 and December 2000. LER [Dave, 1977; Bhartia et al., 1993] is the value of the Lambertian spectral surface albedo for which the modeled and measured reflec- a)

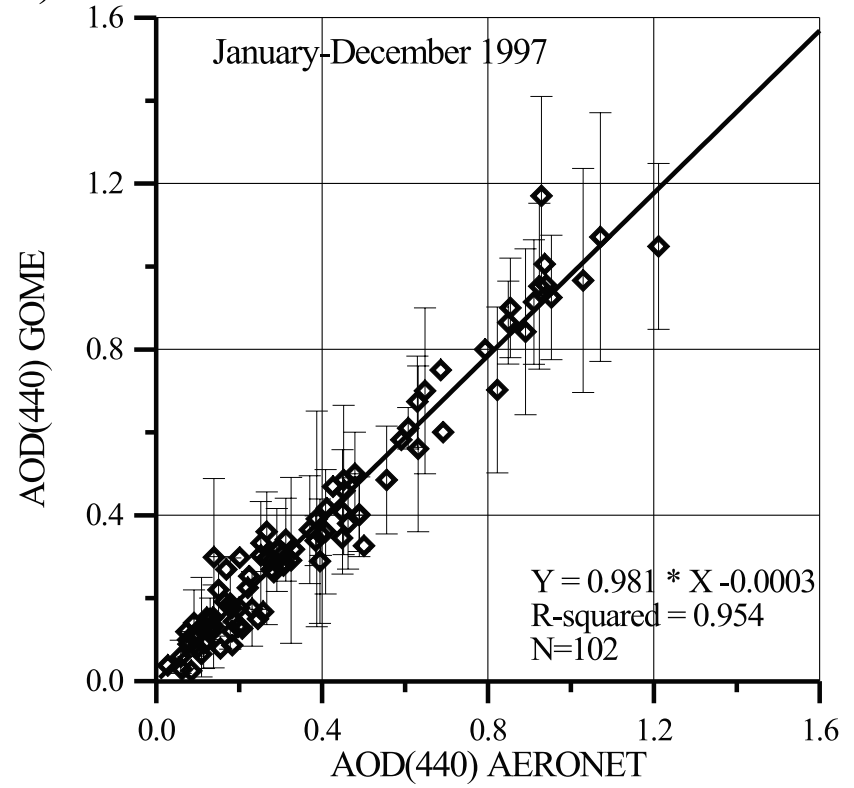

b)

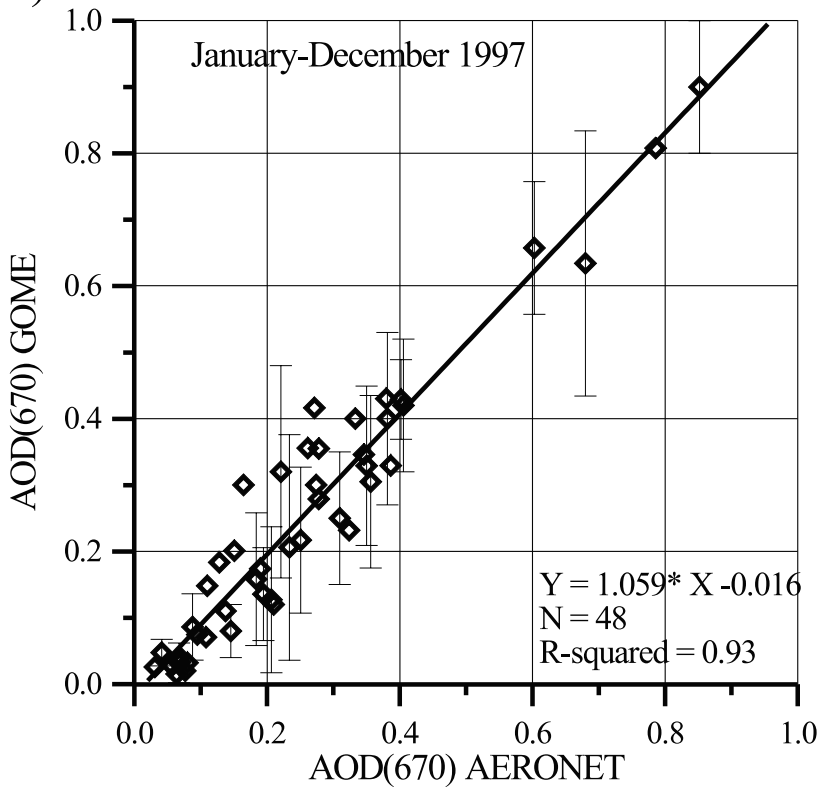

Figure 3. Comparison of the GOME retrieved aerosol optical thickness and the AERONET Sun photometer measurements at (a) $440 \mathrm{~nm}$ and (b) $670 \mathrm{~nm}$. Also shown is an intercomparison for three main aerosol types: (c and d) maritime, (e and f) continental, and (g and h) urban. 
c)

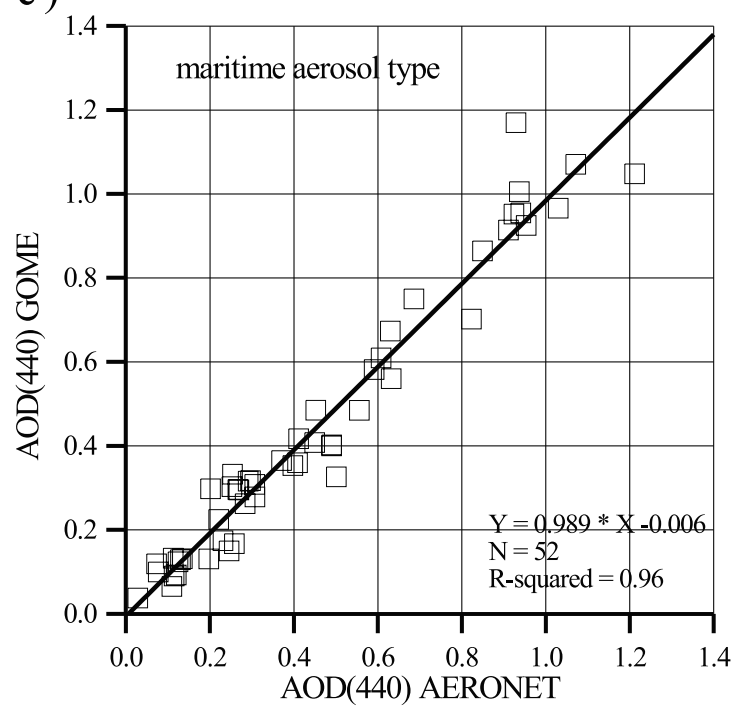

e)

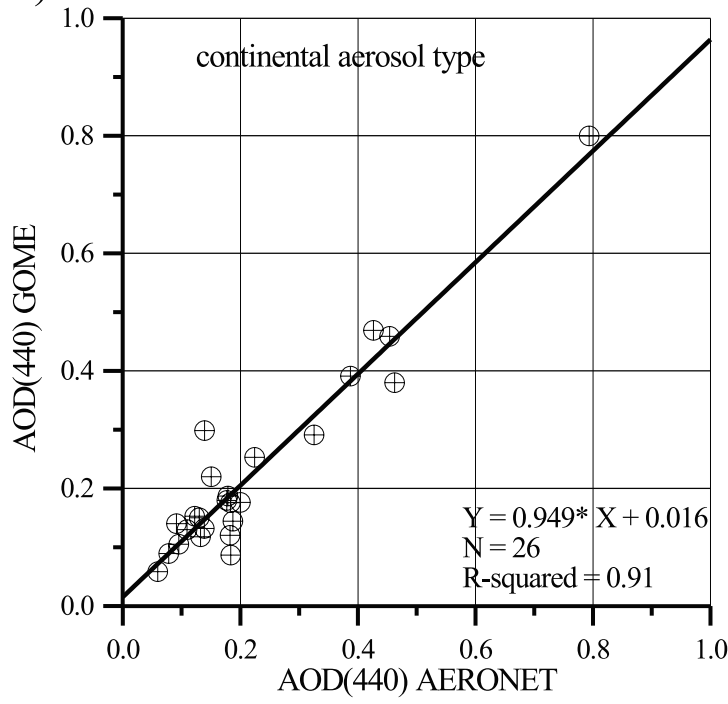

g)

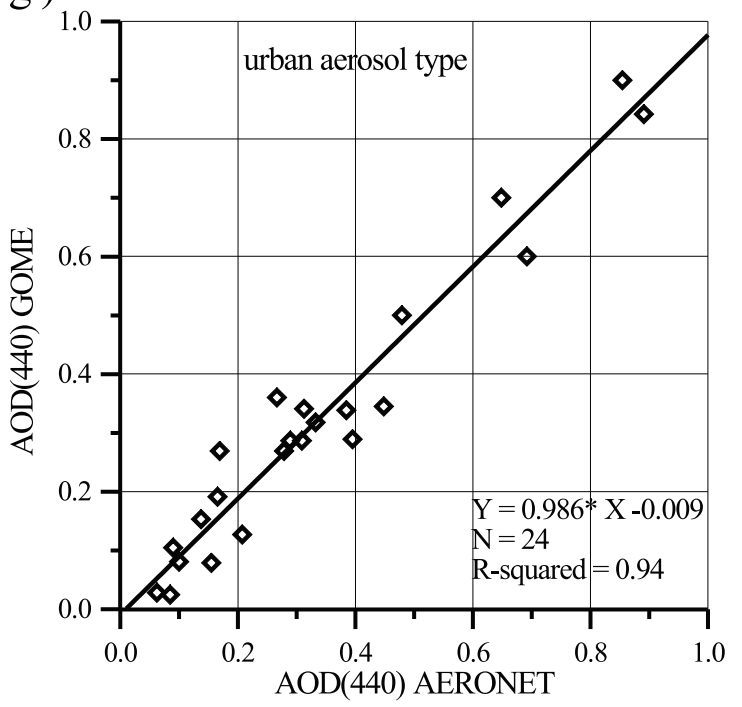

d)

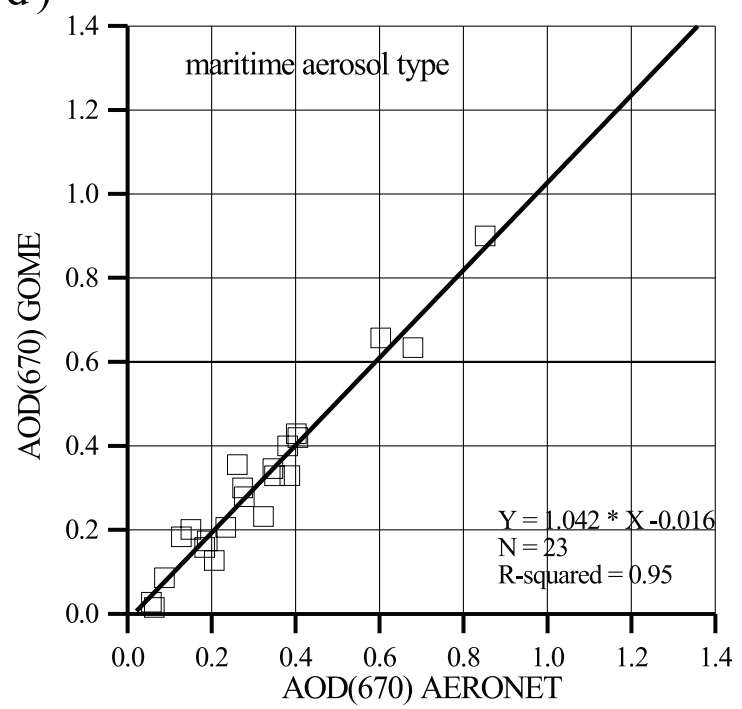

f)

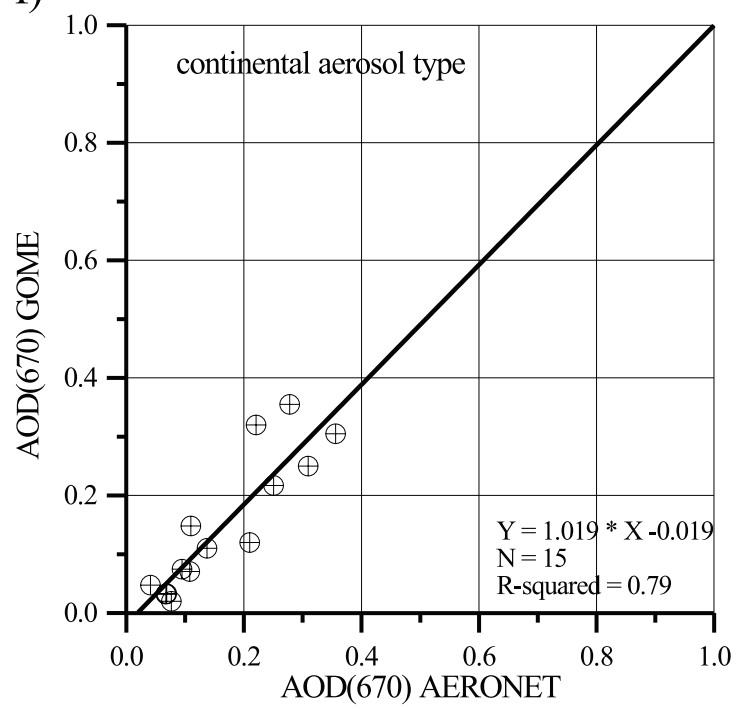

h)

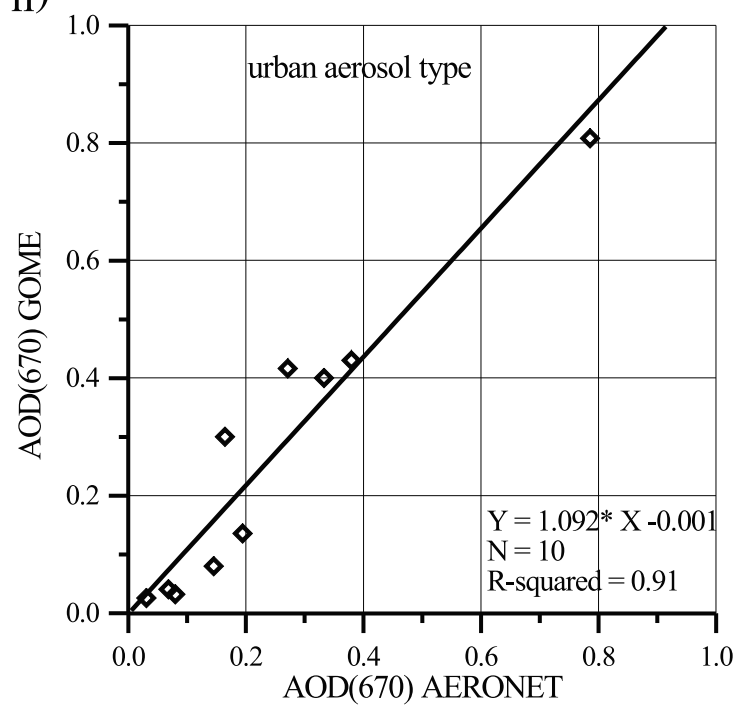

Figure 3. (continued) 
a)



b)

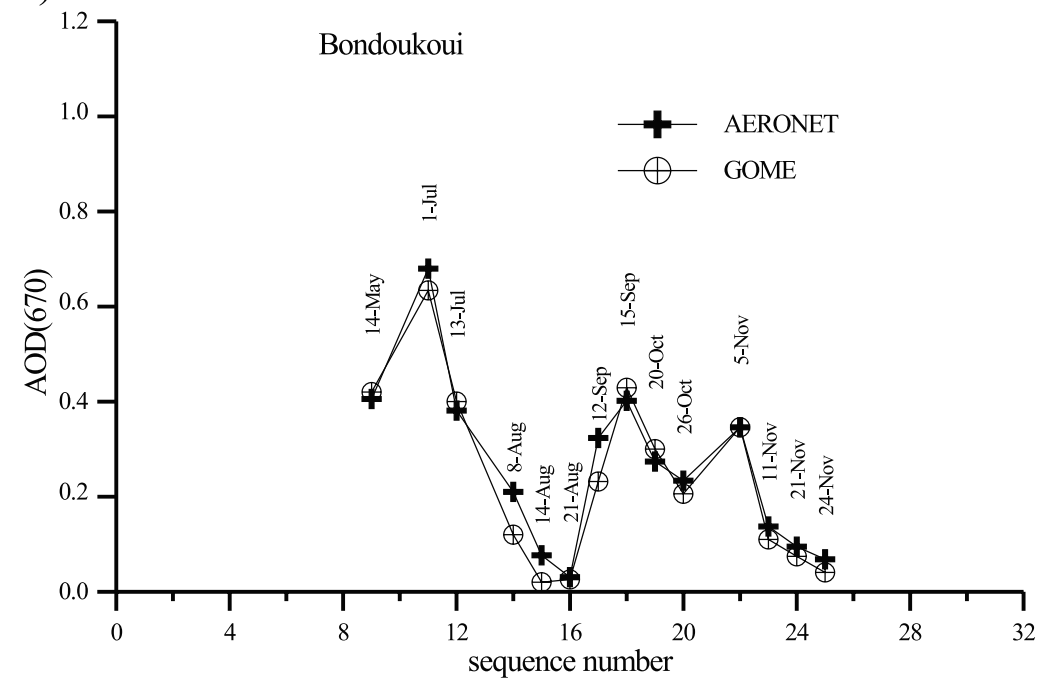

c)

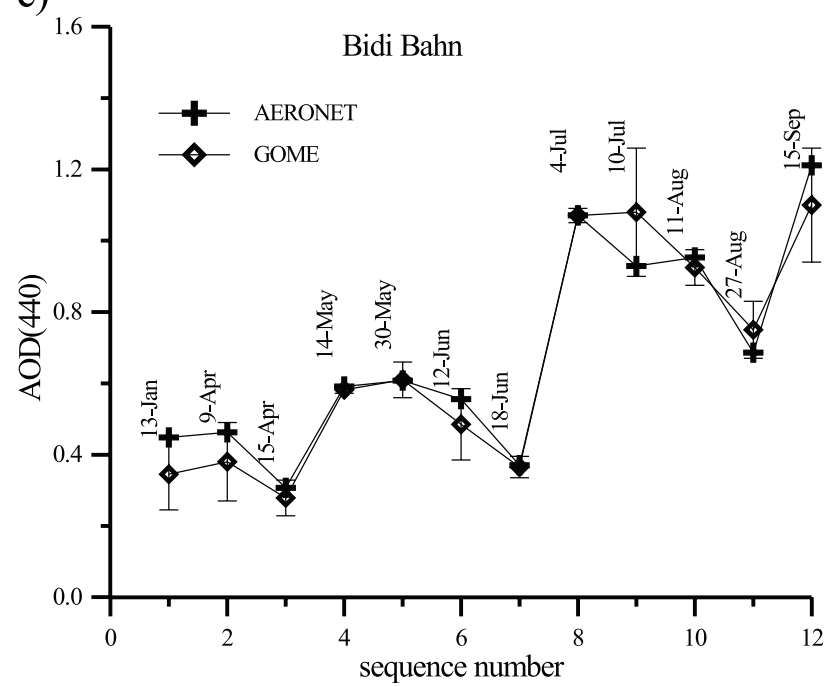

Figure 4. Time series of the aerosol optical thickness retrieved from GOME (diamonds) and measured by Sun photometers (crosses) in 1997: (a) Bondoukoui, $440 \mathrm{~nm}$; (b) Bondoukoui, $670 \mathrm{~nm}$; and (c) Bidi Bahn, $440 \mathrm{~nm}$. 
a)

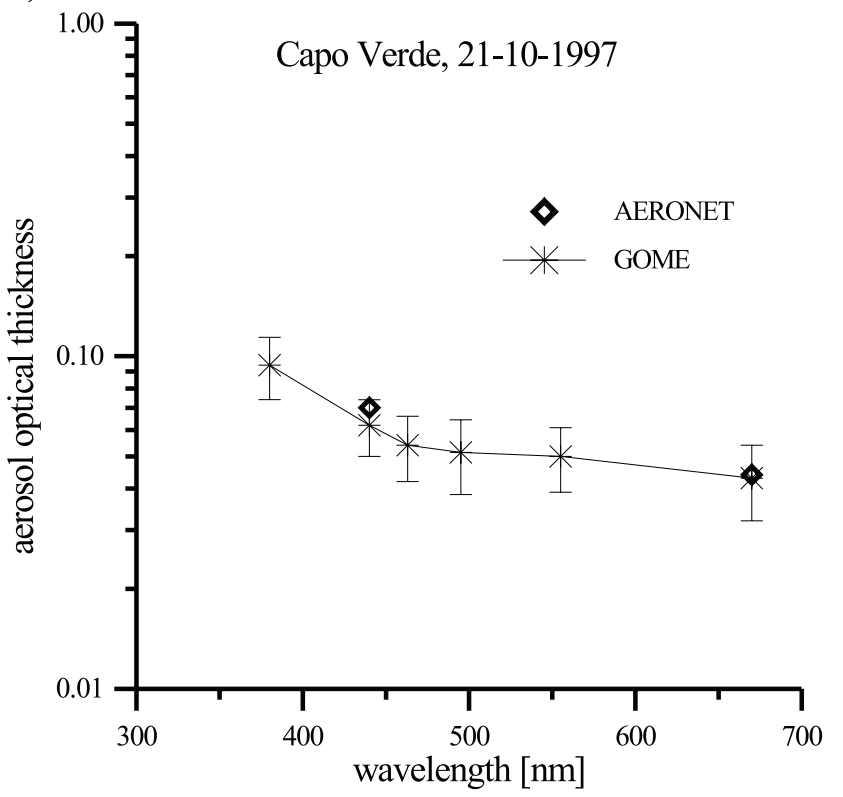

b)

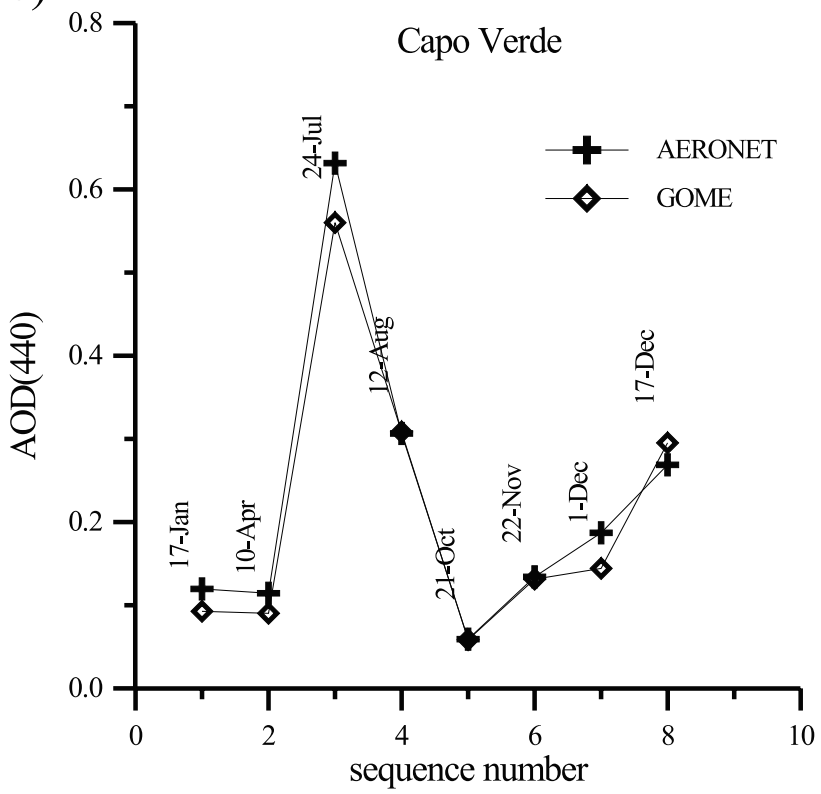

c)



Figure 5. Comparison of the aerosol optical thickness retrieved from GOME with the Sun photometer measurements in Capo Verde in 1997. (a) An example of the "spectral" variation, (b) time series for $440 \mathrm{~nm}$, and (c) time series for $670 \mathrm{~nm}$.

tance at the top of the atmosphere are equal, assuming a Rayleigh scattering atmosphere above a Lambertian surface in the radiative transfer model. Bhartia et al. [1993] and Herman and Celarier [1997] show that LER may be regarded as an estimate of the value of the bidirectional reflectance distribution function (BRDF). Therefore we use this value as equivalent to $\rho_{\text {surf }}$ in equation (1).

[30] The GOME database includes information of the surface reflectance for a given wavelength and month of the year, with a spatial resolution of $1 \times 1^{\circ}$. In the case of the large GOME pixels, using this database is more efficient than trying to differentiate between different types of vegetation and soils. If the value from the database does not allow to solve equation (1) then a bisection method is combined with an iteration method [Press et al., 1992]. The values of the surface reflectance are checked in the range between 0 and $R_{\text {surf }}$, where the upper limit is indicated by the value from the GOME database. If the value of $\mathrm{R}_{\text {surf }}$ from the GOME database causes that the surface term is higher than the input TOA reflectance, then iteratively $R_{\text {surf }}$ is lowered in each next step by $10 \%$ until equation (1) can be solved. The lowest value of $R_{\text {surf }}$ is 0 . There is no 
correction for the opposite situation: the surface reflectance from the database is much lower than the real one. Such situation took place in case of very bright surface. In that case too little surface reflectance was subtracted and the aerosol optical thickness was much higher than the threshold value.

[31] Over water, the proper surface correction is also important, especially in the UV and the visible part of spectrum. In that range the contribution of the water-leaving reflectance to the TOA reflectance is the most significant, around $60 \%$, depending on the type of water and atmosphere. This contribution decreases with the wavelength, reaching at $670 \mathrm{~nm}$ around $1-8 \%$. For Case I waters [Morel, 1988], i.e., mainly oceanic waters which optical properties are determined by phytoplankton and their immediate derivatives, the contribution at $670 \mathrm{~nm}$ will be almost negligible, because the water-leaving reflectance is close to zero. For Case II waters [Morel, 1988], i.e., all coastal waters which optical properties are also determined by the presence of sediments or dissolved yellow substances, this contribution can be much higher.

[32] In addition to the correction for the water-leaving reflectance also the Sun glint correction is done, using the Cox and Munk [1954a, 1954b, 1955] formulae, assuming a mean wind speed of $8 \mathrm{~m} / \mathrm{s}$. When the Sun glint reflectance was higher than 0.001 the pixel was marked as Sun glint contaminated [e.g., Veefkind and de Leeuw, 1998].

\section{Validation}

\subsection{Comparison With Collocated Sun Photometer Measurements}

[33] To test the accuracy of the GOME aerosol algorithm, the retrieved aerosol optical thickness values were compared with collocated Sun photometer measurements (level 2.0), available from the AERONET Web page (//aeronet.gsfc.nasa.gov). Validation was done for 1997. Validation for 2000 was done for only a few sites with similar results.

[34] Comparison of the GOME derived aerosol optical thickness was made for several sites (Table 2), representing different types of surface, and aerosols. To avoid the cloud contamination in the GOME aerosol retrieval, all data for which cloud fraction was higher than $6 \%$ were removed. Comparisons were made for the same site, day, and hour, therefore it was more difficult to find collocated measurements. The list of sites together with the mean absolute difference between satellite and Sun photometer measurement, as well as the correlation coefficients for each site is presented in Table 2.

[35] Figures $3 \mathrm{a}$ and $3 \mathrm{~b}$ show comparisons of the available data for 1997, for the wavelengths of $440 \mathrm{~nm}$ and $670 \mathrm{~nm}$, for all sites listed in Table 2. In some cases, for the sites characterized by a high surface reflectance at $670 \mathrm{~nm}$ (see section 3.2 for detail), the aerosol optical thickness was not retrieved, and it is indicated in Table 2. The error bars of the GOME data were obtained from averaging over an area of $0.5^{\circ} \times 0.5^{\circ}$. The high correlation gives confidence that the aerosol retrieval algorithm works well.

[36] Figures $3 c-3 h$ present intercomparison for each main aerosol type. It turns out that among all observations, the "maritime" aerosol type was the most frequently observed. Nevertheless, the high correlation coefficients indicate that the retrievals have no bias for specific types of aerosols.

[37] Figures $4 a-4 c$ present comparisons of the aerosol optical thickness retrieved from GOME and from ground measurements, for Bondoukoui and Bidi Bahn, for the year 1997. The results show good agreement both for small values of the aerosol optical thickness (around 0.05) and for higher values (more than 0.6).

[38] Figure 5a presents an example of the "spectral" comparison, for two AERONET wavelengths: $440 \mathrm{~nm}$ and $670 \mathrm{~nm}$, for site Capo Verde that is regarded as a representation of the oceanic and dust particles. Figures $5 \mathrm{~b}$ and $5 \mathrm{c}$ show the time series of the aerosol optical thickness derived for $440 \mathrm{~nm}$ and $670 \mathrm{~nm}$, respectively. This comparison proves that the aerosol algorithm works well also for the low values of the aerosol optical thickness.

[39] Figures 6a and 6b present the "spectral" comparison for two sites in Europe, in 2000: Venice (Italy) and Avignon (France). The Sun photometer in Venice has two more channels, in the range from $380 \mathrm{~nm}$ to $670 \mathrm{~nm}$, than the standard ones (i.e., $380 \mathrm{~nm}$ and $500 \mathrm{~nm}$ ), therefore the comparison was also possible for the UV values (Figure 6a).

\subsection{Sources of Uncertainty in the Aerosol Optical Thickness}

[40] One of the main sources of uncertainty in the retrieval of aerosol optical thickness is the surface reflectance. On the other hand, errors in the radiometric calibration of GOME and errors caused by residual cloud contamination lead to uncertainty in the derived LER values. Koelemeijer et al. [2003] estimated for the Libyan Desert site that the absolute errors in the derived LER values due to degradation in optical components of the GOME instrument do not exceed $0.01-0.02$ for all wavelengths except $335 \mathrm{~nm}$. This implies that for other, less bright, areas absolute errors should be smaller.

[41] The next source of discrepancy between the derived aerosol optical thickness and Sun photometer measurements (see Table 2) is related to the pixel size. The ground Sun photometer measurements are assumed to be representative for the whole GOME pixel area of $40 \times 320 \mathrm{~km}^{2}$. This implies that variations between the retrieved and the measured values of the aerosol optical thickness might be caused by variability in the area observed by GOME (or presence of small clouds). Owing to the large GOME pixel size the classical approach to the surface correction based on the vegetation index NDVI would not be sufficient because GOME pixels are often inhomogeneous due to presence of surfaces with different reflectances throughout the pixel. Therefore the application of the GOME surface reflectance database is more accurate.

[42] To estimate the absolute error in the surface reflectance from the GOME database the "effective" surface reflectance was calculated for each AERONET site (Tables 2 and 3). Using the aerosol optical thickness measured by the Sun photometers and the TOA reflectance from GOME, the "effective" surface reflectance for the pixel area observed by GOME was calculated (equation (1)). The results are presented in Table 3. The absolute error varies with wavelength and geographical location. The 

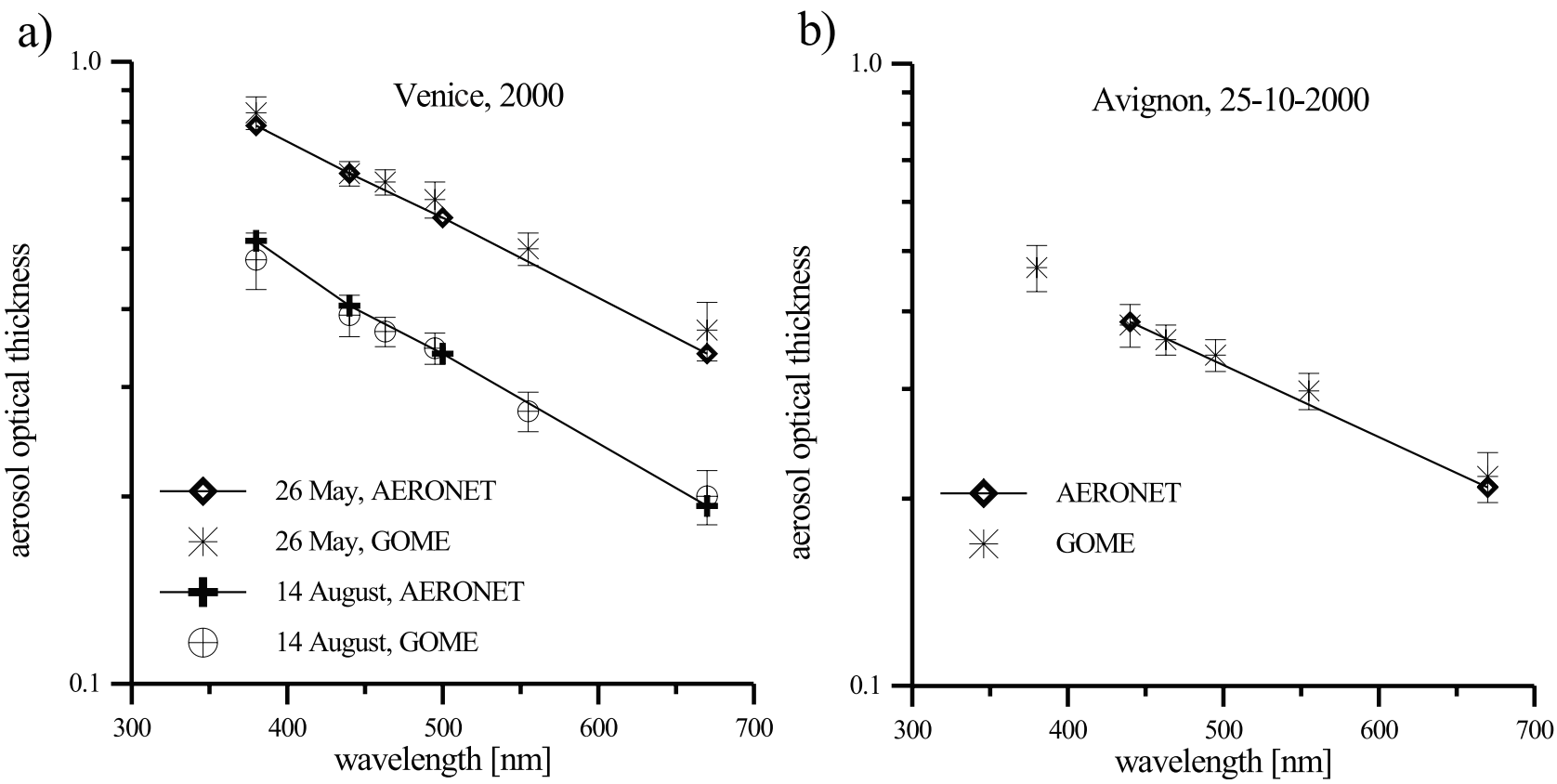

Figure 6. Comparison of the aerosol optical thickness retrieved from GOME with the Sun photometer measurements in 2000: (a) Venice and (b) Avignon.

results indicate that in many cases the values in the GOME database were underestimated. As was mentioned in section 3.2 we do not correct for this situation. The largest discrepancy was found for the Banizombou site, i.e., 0.075 at $670 \mathrm{~nm}$. The high underestimation in the surface reflectance at this wavelength resulted in a large overestimation of the retrieved aerosol optical thickness. Because the resulting value was much higher than the threshold it was rejected (see section 3). However, the mean absolute error in the surface reflectance does not exceed 0.03 at $440 \mathrm{~nm}$ and 0.029 at $670 \mathrm{~nm}$.

[43] There are other sources of uncertainties in the aerosol optical thickness, e.g., related to specific aerosol models. However, all these errors are already taken into account by comparing real measurements and retrieved values and listed in Table 2 as absolute errors. The mean absolute error for the aerosol optical thickness at $440 \mathrm{~nm}$ is 0.04 and at $670 \mathrm{~nm}$ it is 0.03 .

\section{Aerosol Optical Thickness Spatial Distribution}

[44] Having established that the algorithm provides reliable results as determined from comparison with AERONET Sun photometer data over Europe and Africa, the spatial distribution of the aerosol optical thickness values over this part of the world has been determined for 1997 and 2000. The data are presented for the region of the North Atlantic and Europe (i.e., latitude from $5^{\circ} \mathrm{N}$ to $70^{\circ} \mathrm{N}$ and longitude from $80^{\circ} \mathrm{W}$ to $70^{\circ} \mathrm{E}$ ). Over Europe there are regions with high values of the aerosol optical thickness due to anthropogenic activities as well as rural regions where the aerosol optical thickness is low [Robles Gonzalez et al., 2000]. Over Africa, Sahara desert dust dominates, and it is transported over the Atlantic throughout the year [e.g., Chiapello and Moulin, 2002]. In the winter, there is also a strong transport of carbonaceous aerosols from African region north of the equator [Herman et al., 1997].

[45] Owing to the large fraction of cloud contaminated pixels, only few valid data are left. Therefore the data have been combined to represent three periods, i.e., the "European summer," i.e., May, June, July, and August (MJJA), the "European winter," i.e., January, February, November, and December (JFND) and the other months, i.e., March, April, September, and October (MASO), to represent the interseasonal changes. The results are presented on Figures $7 \mathrm{a}-7 \mathrm{e}$, for the wavelength of $440 \mathrm{~nm}$.

[46] Figures 7a and 7b present the "winter" spatial distribution of the aerosol optical thickness for the year 1997 and 2000. For latitudes higher than $40^{\circ} \mathrm{N}$ there is no data because of two reasons: presence of clouds and

Table 3. Absolute Error in the Surface Reflectance for the Same AERONET Sites As in Table $2^{\text {a }}$

\begin{tabular}{llcc}
\hline \multicolumn{1}{c}{ Site } & Location & $\left|\Delta \rho_{\text {surf }}(440)\right|$ & $\left|\Delta \rho_{\text {sur }}(670)\right|$ \\
\hline Banizombou & $13 \mathrm{~N}, 2 \mathrm{E}$ & 0.039 & 0.075 \\
Bondoukoui & $11 \mathrm{~N}, 3 \mathrm{~W}$ & 0.018 & 0.015 \\
Barbados & $13 \mathrm{~N}$, 59W & 0.021 & 0.014 \\
Capo Verde & $16 \mathrm{~N}, 22 \mathrm{~W}$ & 0.025 & 0.023 \\
Rame Head & $50 \mathrm{~N}, 4 \mathrm{~W}$ & 0.016 & 0.006 \\
Bidi Bahn & $14 \mathrm{~N}, 2 \mathrm{~W}$ & 0.025 & 0.045 \\
Dakar & $14 \mathrm{~N}, 16 \mathrm{~W}$ & 0.063 & 0.049 \\
GSFC & $39 \mathrm{~N}, 76 \mathrm{~W}$ & 0.035 & 0.031 \\
Lille & $50 \mathrm{~N}, 3 \mathrm{E}$ & 0.051 & 0.023 \\
Ispra & $45 \mathrm{~N}, 8 \mathrm{E}$ & 0.042 & 0.036 \\
Bermuda & $32 \mathrm{~N}, 64 \mathrm{~W}$ & 0.007 & 0.009 \\
Aire Adour & $43 \mathrm{~N}, 0 \mathrm{E}$ & 0.019 & 0.025 \\
\hline
\end{tabular}

${ }^{\text {a}}$ Here $\left|\Delta \rho_{\text {surf }}(440)\right|$ and $\left|\Delta \rho_{\text {surf }}(670)\right|$ are the mean absolute differences between the surface reflectance from the GOME database and the "effective" surface reflectance calculated for a given site at 440 and $670 \mathrm{~nm}$, respectively. The "effective" surface reflectance was estimated using the Sun photometer measurements and the TOA reflectance from GOME for collocated measurements. 
a)

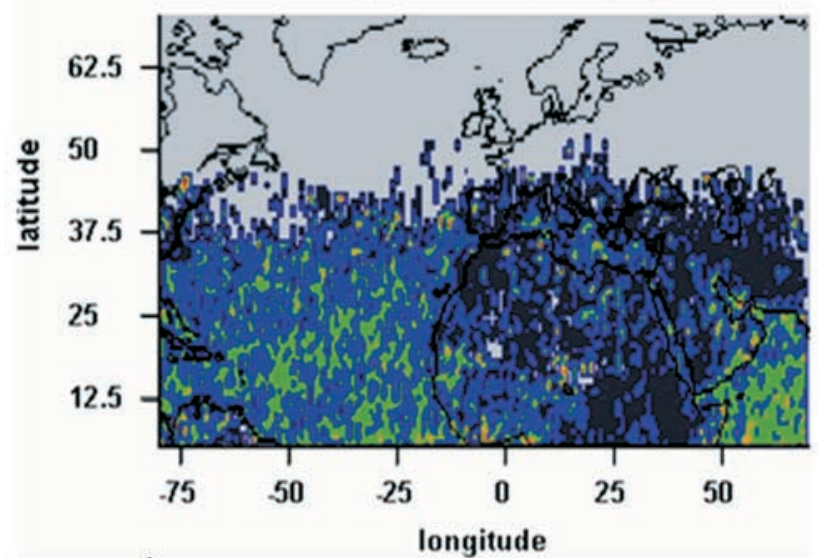

c)



e)

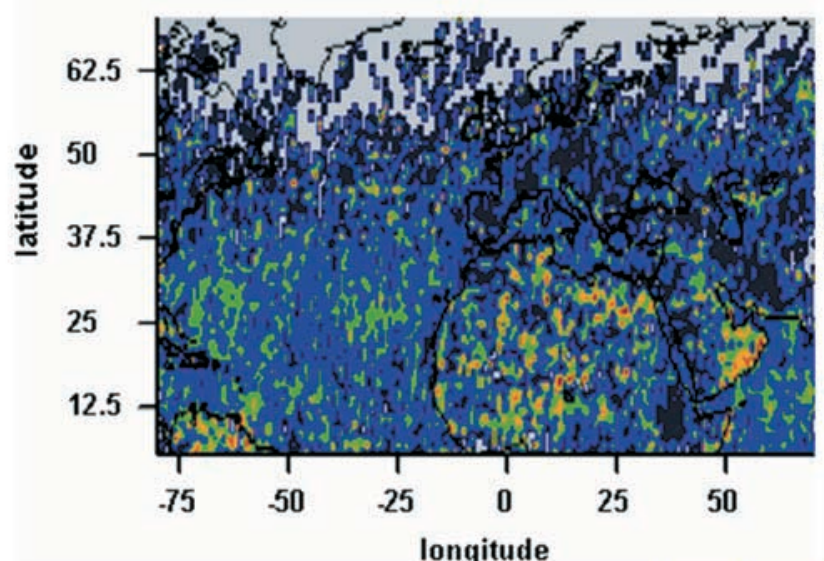

b)

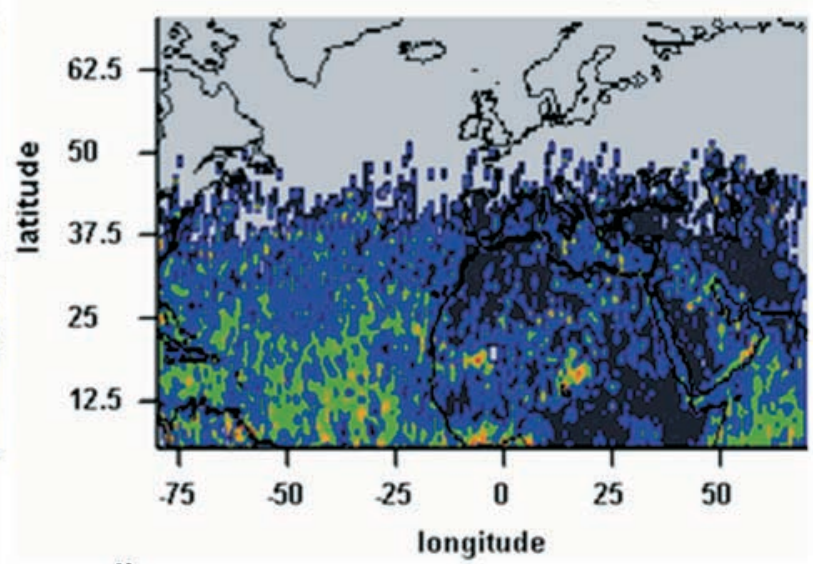

d)

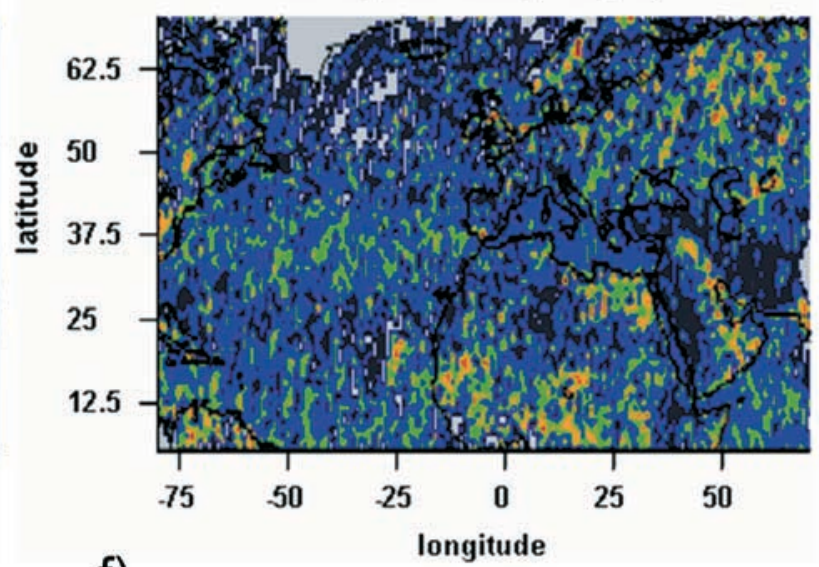

f)

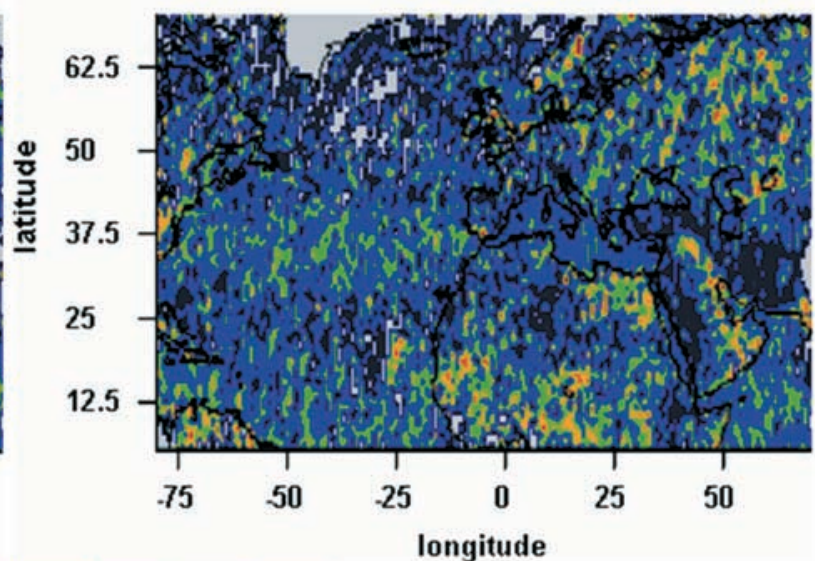

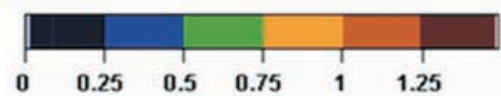

Figure 7. Spatial AOD distributions determined from GOME data that were combined in three groups representing: ( $a$ and b) winter (January, February, November, and December), (c and d) summer (May, June, July, and August), and (e and f) intermediate period (March, April, September, and October), for the years 1997 and 2000. 
limitation of retrieval to data representing the solar zenith angles $\leq 60^{\circ}$. The spatial distribution of the aerosol optical thickness for both years looks very similar. The plume close to Africa, observed also by other satellites [Myhre et al., 2004], despite of large GOME pixels, is also visible. The mean values of the aerosol optical thickness inside the plume are in the range between 0.5 and 1 . Outside the plume the values are much lower, around 0.25 . This plume is not as clear as it is often observed from other satellite [e.g., Bellouin, 2003]. One of the reasons could be that areas with high AOD may be assigned as cloud contaminated. For comparison, Holzer-Popp et al. [2002] exclude GOME pixels with cloud fraction above 50\%, North [2002] uses ATSR-2 data with cloud fraction less than $20 \%$. When we allow for higher cloud fraction in our retrievals, the Saharan dust plume is much more clearly visible. Obviously this is not a true presentation of AOD. For instruments with small pixels, allowing for more cloud-free pixels, this problem will disappear.

[47] Figures 7c and 7d present the "summer" aerosol maps. The location of areas with high values of the aerosol optical thickness over Africa (i.e., in the range between 0.75 and 1.5), correspond also to the distribution of the high values of TOMS AAI (www.toms.gsfc.nasa.gov) that is related to the dust optical thickness [e.g., Chiapello and Moulin, 2002]. Comparison of the "summer" aerosol optical thickness for Europe indicates that in 2000, in the eastern part of Europe, the values were much higher than in 1997. The spatial distribution of the aerosol optical thickness for Europe in summer 1997 is in agreement with the aerosol map of Europe for August 1997, derived from ATSR-2 [Robles Gonzalez et al., 2000]. Again the large GOME pixels are disadvantage, because they disable the smooth, detailed spatial distribution of the aerosol optical thickness. The plume close to Africa is less visible than in winter.

[48] Figures 7e and $7 \mathrm{f}$ present the mean values of the aerosol optical thickness for the period of 4 months, including European spring and autumn. For that period the distribution of the aerosol optical thickness, for both years, is very similar. The location of areas with high AOD over Africa resembles the situation for "summer." The values of the aerosol optical thickness over Europe, in spring-autumn period, for both years are much lower than for the summer period and their spatial distribution is more uniform than in summer, with an exception of the east Europe, where there are areas with high values, AOD > 0.75 .

\section{Conclusions}

[49] The GOME aerosol retrieval algorithm works well, where it can be assumed that the pixels are cloud free, such as in the case of comparison with level 2.0 Sun photometer data. Because of high probability of cloud contamination, therefore GOME is not suitable for monitoring aerosols on a daily or even on a monthly base. The value of GOME aerosol data may be that they can be retrieved over land and over ocean, for the lifetime of the instrument, on a global scale. In particular the AOD values over land are complementary to the data over ocean from other instruments. The GOME data can be retrieved from June 1995 to December 2000 and the series will be extended with satellite instru- ments covering the similar wavelengths as GOME, e.g., SCIAMACHY, GOME-2 and OMI. The advantage of these instruments is the smaller pixel size allowing for less cloud contamination and more accurate determination of the surface reflectance. In addition, SCIAMACHY has a wider spectral range (up to $2400 \mathrm{~nm}$ ) than GOME (up to $790 \mathrm{~nm}$ ). The spectral information from the IR channels can be used to better discriminate dust particles and for the elimination of clouds. Moreover the unique feature of SCIAMACHY-limb viewing geometry can be used for stratospheric retrieval.

[50] Acknowledgments. We thank the PI investigators: Didier Tanré, Brent Holben, Philippe Goloub, and Giuseppe Zibordi, and their staff for establishing and maintaining the AERONET sites used in this investigation. We acknowledge Piet Stammes and Martin de Graaf for kindly providing us GOME data and the results from FRESCO algorithm. We thank Darek Maksimiuk for his help in solving the software problems, Roman Marks for helpful discussion, and Marianne Degache and Robin Schoemaker for their support. The algorithm was developed as part of the EO-037 project of the National Data User Support Program of the Netherlands Space Research Organization (SRON)

\section{References}

Aitken, J. (1890), On the number of dust particles in the atmosphere of certain places in Great Britain and on the continent, with remarks on the relation between the amount of dust and meteorological phenomena, Proc. R. Soc. Edinburgh, 17, 76-93.

Bellouin, M. N. (2003), Estimation de l'effect direct des aerosols à partir de la modélisation et de la télédétection passive, Ph.D. thesis, 186 pp., Univ. Sci. Technol. Lille, Lille, France.

Bhartia, P. K., J. R. Herman, and R. D. McPeters (1993), Effect of Mount Pinatubo aerosols on total ozone measurements from backscatter ultraviolet (BUV) experiments, J. Geophys. Res., 98, 18,547-18,554

Brasseur, G. P., J. J. Orlando, and G. S. Tyndall (1999), Atmospheric Chemistry and Global Change, 654 pp., Oxford Univ. Press, New York. Burrows, I. P., et al. (1999), The Global Ozone Monitoring Experiment (GOME): Mission concept and first scientific results, J. Atmos. Sci., $56,151-175$.

Charlson, R. J., J. Langner, H. Rodhe, C. B. Leovy, and S. G. Warren (1991), Perturbation of the Northern Hemisphere radiative balance by backscattering from anthropogenic sulfate aerosols, Tellus Ser. AB, 43, $152-163$

Chiapello, I., and C. Moulin (2002), TOMS and METEOSAT satellite records of the variability of Saharan dust transport over the Atlantic during the last two decades (1979-1997), Geophys. Res. Lett., 29(8), 1176, doi:10.1029/2001GL013767.

Cohen, J. B., and A. G. Ruston (1912), Smoke: Study of Town Air, 16 pp., Edward Arnold, London.

Cox, C., and W. Munk (1954a), Statistics of the sea surface derived from Sun glitter, J. Mar. Res., 13, 198-227.

Cox, C., and W. Munk (1954b), Measurement of the roughness of the sea surface from photographs of the Sun's glitter, J. Opt. Soc. Am., 44, 838850.

Cox, C., and W. Munk (1955), Some problems in optical oceanography, J. Mar. Res., 14, 63-78.

Dave, J. V. (1977), Investigation of the effect of atmospheric dust on the determination of total ozone from the Earth's ultraviolet reflectivity measurements, NTIS-N77-24690-24692, Natl. Tech. Inf. Serv., Springfield, Va.

Dubovik, O., B. Holben, T. F. Eck, A. Smirnov, Y. J. Kaufman, M. D. King, D. Tanré, and I. Slutsker (2002), Variability of absorption and optical properties of key aerosol types observed in worldwide locations, $J$. Atmos. Sci., 59, 590-608

Eck, T. F., B. N. Holben, J. S. Reid, O. Dubovik, A. Smirnov, N. T. O’Neill, I. Slutsker, and S. Kinne (1999), Wavelength dependence of the optical depth of biomass burning, urban, and desert dust aerosol, J. Geophys. Res., 104, 31,333-31,350.

Fyfe, P. (1911), Air pollution in Glasgow and other towns in Scotland, paper presented at Conference of Smoke Abatement League of Great Britain, Manchester, UK.

Gibbs, W. (1929), Аэрозоли (in Russian), 240 pp., Leningrad.

Guzzi, R., G. Ballista, W. Di Nicolantonio, and E. Carboni (2001), Aerosol maps from GOME data, Atmos. Environ., 35, 5079-5091. 
Haxby, W. F., G. D. Karner, J. L. La Brecque, and J. K. Weissel (1983), Digital images of combined oceanic and continental data sets and their use in tectonic studies, Eos Trans. AGU, 64, 995-1004.

Herman, J. R., and E. A. Celarier (1997), Earth surface reflectivity climatology at 340-380 nm from TOMS data, J. Geophys. Res., 102, 28,00328,011 .

Herman, J. R., P. K. Bhartia, O. Torres, C. Hsu, C. Seftor, and E. Celarier (1997), Global distributions of UV-absorbing aerosols from NIMBUS 7 TOMS data, J. Geophys. Res., 102, 16,911-16,922.

Holben, B. N., et al. (1998), AERONET-A federated instrument network and data archive for aerosol characterisation, Remote Sens. Environ., 66(1), $1-16$.

Holzer-Popp, T., M. Schroedter, and G. Gesell (2002), Retrieving aerosol optical depth and type in the boundary layer over land and ocean from simultaneous GOME spectrometer and ATSR-2 radiometer measurements, 1, Method description, J. Geophys. Res., 107(D21), 4578, doi:10.1029/2001JD002013.

Kaufman, Y. J., and D. Tanré (1996), Strategy for direct and indirect methods for correcting the aerosol effect on remote sensing: From AVHRR to EOS-MODIS, Remote Sens. Environ., 55, 65-79.

Koelemeijer, R. B. A., P. Stammes, J. W. Hovenier, and J. F. de Haan (2001), A fast method for retrieval of cloud parameters using oxygen A band measurements from GOME, J. Geophys. Res., 106, 3475-3490.

Koelemeijer, R. B. A., P. Stammes, J. W. Hovenier, and J. F. de Haan (2002), Global distributions of effective cloud fraction and cloud top pressure derived from oxygen A band spectra measured by the Global Ozone Monitoring Experiment: Comparison to ISCCP data, J. Geophys. Res., 107(D12), 4151, doi:10.1029/2001JD000840.

Koelemeijer, R. B. A., J. F. de Haan, and P. Stammes (2003), A database of spectral surface reflectivity in the range $335-772 \mathrm{~nm}$ derived from 5.5 years of GOME observations, J. Geophys. Res., 108(D2), 4070, doi:10.1029/2002JD002429.

Kusmierczyk-Michulec, J., and R. Marks (2000), The influence of sea-salt aerosols on the atmospheric extinction over the Baltic and the North Seas, J. Aerosol Sci., 31(11), 1299-1316.

Kusmierczyk-Michulec, J., O. Krueger, and R. Marks (1999), Aerosol influence on the sea-viewing wide-field-of-view sensor bands: Extinction measurements in a marine summer atmosphere over the Baltic Sea, J. Geophys. Res., 104(D12), 14,293-14,307.

Kusmierczyk-Michulec, J., M. Schulz, S. Ruellan, O. Krueger, E. Plate, R. Marks, G. de Leeuw, and H. Cachier (2001), Aerosol composition and related optical properties in the marine boundary layer over the Baltic Sea, J. Aerosol Sci., 32(8), 933-955.

Kusmierczyk-Michulec, J., G. de Leeuw, and C. R. Gonzalez (2002), Empirical relationships between aerosol mass concentrations and Angström parameter, Geophys. Res. Lett., 29(7), 1145, doi:10.1029/ 2001 GL014128.
Lenoble, J. (1985), Radiative Transfer in Scattering and Absorbing Atmospheres: Standard Computational Procedures, 300 pp., A. Deepak, Hampton, Va.

McClatchey, R. A., H. J. Bolle, K. Y. Kondratyev, J. H. Joseph, M. P. McCormick, E. Raschke, J. B. Pollack, D. Spänkuch, and C. Mateer (1984), A preliminary cloudless standard atmosphere for radiation computation, 53 pp., Int. Radiat. Comm., Boulder, Colo.

Morel, A. (1988), Optical modeling of the upper ocean in relation to its biogenous matter content (case I waters), J. Geophys. Res., 93, 10,74910,768 .

Myhre, G., et al. (2004), Intercomparison of satellite retrieved aerosol optical depth over ocean, J. Atmos. Sci., 61, 499-513.

North, P. R. J. (2002), Estimation of aerosol opacity and land surface bidirectional reflectance from ATSR-2 dual-angle imagery: Operational method and validation, J. Geophys. Res., 107(D12), 4149, doi:10.1029/ 2000JD000207.

Press, W. H., S. A. Teukolsky, W. T. Vetterling, and B. P. Flannery (1992), Numerical Recipes in C: The Art of Scientific Computing, 994 pp., Cambridge Univ. Press, New York.

Robles Gonzalez, C., J. P. Veefkind, and G. de Leeuw (2000), Aerosol optical depth over Europe in August 1997, derived from ATSR-2 data, Geophys. Res. Lett., 27(7), 955-958.

Schwartz, S. E. (1996), The Whitehouse effect, shortwave radiative forcing of climate by anthropogenic aerosols: An overview, J. Aerosol Sci., 27 , $359-382$.

Shettle, E. P. (1984), Optical and radiative properties of a desert aerosol model, in Symposium of Radiation in the Atmosphere, 74-77 pp., A. Deepak, Hampton, Va.

Smirnov, A., B. N. Holben, T. F. Eck, O. Dubovik, and I. Slutsker (2000), Cloud screening and quality control algorithms for the AERONET data base, Remote Sens. Environ., 73(3), 337-349.

Tanré, D., M. Herman, P. Y. Deschamps, and A. de Leffe (1979), Atmospheric modeling for space measurements of ground reflectances, including bidirectional properties, Appl. Opt., 18(21), 3587-3594.

Veefkind, J. P., and G. de Leeuw (1998), A new algorithm to determine the spectral aerosol optical depth from satellite radiometer measurements, J. Aerosol Sci., 29, 1237-1248.

Vermote, E. F., D. Tanré, J. L. Deuzé, M. Herman, and J.-J. Morcrette (1997), Second Simulation of the Satellite Signal in the Solar Spectrum, 6S: An overview, IEEE Trans. Geosci. Remote Sens., 35(3), $675-686$.

G. de Leeuw and J. Kusmierczyk-Michulec, Physics and Electronics Laboratory, Netherlands Organization for Applied Scientific Research, P.O. Box 96864, N-2509 JG The Hague, Netherlands. (michulec@fel.tno.nl) 